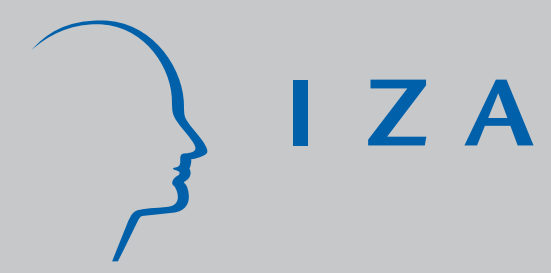

IZA DP No. 7133

Immigrant Workers and Farm Performance:

Evidence from Matched Employer-Employee Data

Nikolaj Malchow-Møller

Jakob Roland Munch

Claus Aastrup Seidelin

Jan Rose Skaksen

January 2013 


\title{
Immigrant Workers and Farm Performance: Evidence from Matched Employer-Employee Data
}

\author{
Nikolaj Malchow-Møller \\ University of Southern Denmark \\ and CEBR \\ Jakob Roland Munch \\ University of Copenhagen, \\ CEBR and IZA
}

\author{
Claus Aastrup Seidelin \\ University of Southern Denmark \\ and CEBR
}

Jan Rose Skaksen

CEBR, Copenhagen Business School

CEBR and IZA

Discussion Paper No. 7133

January 2013

\author{
IZA \\ P.O. Box 7240 \\ 53072 Bonn \\ Germany \\ Phone: +49-228-3894-0 \\ Fax: +49-228-3894-180 \\ E-mail: iza@iza.org
}

\begin{abstract}
Any opinions expressed here are those of the author(s) and not those of IZA. Research published in this series may include views on policy, but the institute itself takes no institutional policy positions. The IZA research network is committed to the IZA Guiding Principles of Research Integrity.

The Institute for the Study of Labor (IZA) in Bonn is a local and virtual international research center and a place of communication between science, politics and business. IZA is an independent nonprofit organization supported by Deutsche Post Foundation. The center is associated with the University of Bonn and offers a stimulating research environment through its international network, workshops and conferences, data service, project support, research visits and doctoral program. IZA engages in (i) original and internationally competitive research in all fields of labor economics, (ii) development of policy concepts, and (iii) dissemination of research results and concepts to the interested public.
\end{abstract}

IZA Discussion Papers often represent preliminary work and are circulated to encourage discussion. Citation of such a paper should account for its provisional character. A revised version may be available directly from the author. 


\section{ABSTRACT}

\section{Immigrant Workers and Farm Performance: Evidence from Matched Employer-Employee Data*}

Many developed countries have recently experienced a significant inflow of immigrants in the agricultural sector. At the same time, the sector is still in a process of structural transformation resulting in fewer but bigger and presumably more efficient farms. In this paper, we exploit detailed matched employer-employee data for the entire population of Danish farms in the period 1980-2008 to analyze the micro-level relationship between these two developments. We find that farms that employ immigrants tend to be both larger and at least as productive as other farms. Furthermore, an increased use of immigrants is found to be associated with an improvement in farm performance as measured by job creation and revenue, and this seems at least in part to reflect a causal effect of the immigrants.

JEL Classification: J61, J43

Keywords: immigration, agriculture, matched employer-employee data

Corresponding author:

Jakob R. Munch

Department of Economics

University of Copenhagen

Øster Farimagsgade 5, Building 26

DK-1353 Copenhagen K

Denmark

E-mail: Jakob.Roland.Munch@econ.ku.dk

\footnotetext{
* This paper is part of a joint project between CEBR and the Rockwool Foundation Research Unit. Funding for this project from the Rockwool Foundation is gratefully acknowledged. The authors wish to thank Jan Holst Hansen, Jonas Helth Lønborg, Marianne Deleuran Grunnet and Philip Rosenbaum for excellent research assistance.
} 


\section{Introduction}

In many developed countries, the agricultural sector - or the rural sector more generally - has experienced an increasing number of immigrants in recent years. According to the National Agricultural Worker Survey (NAWS), foreign-born newcomers, who are immigrants that have been in the country for less than a year, increased their contribution to the U.S. farm workforce from 10 percent in 1993-1994 to 16 percent in 2001-2002. ${ }^{1}$ In Europe, countries like Italy, Spain, Portugal and Greece have also experienced a rapid increase in migrant employment in the agricultural sector in the last decades (Kasimis, 2005), and in Denmark, the share of immigrant workers in the agricultural sector increased from less than $2 \%$ in 1993 to close to $13 \%$ in 2008.

Furthermore, the agricultural sector is still in a process of structural transformation where many farms close while others grow larger and presumably more productive. In the US, for example, the number of farms has decreased from around 6 million in the first half of the $20^{\text {th }}$ century to around 2 million by the turn of the century. In the same period, average farm size more than doubled, while agriculture's share in total employment has fallen dramatically. ${ }^{2}$ As we shall see, a similar development has taken place in Denmark.

It is generally believed that migrant labor has helped filling labor deficits and reduced labor costs in agriculture, see, e.g., Kasimis (2005) and Huffman (2005), but the question is whether there is also a more direct micro-level relationship between the use of immigrants and the structural transformation of farms. In other words, does the employment of immigrants help a farm to expand and/or become more productive? Or is it only the farms that grow and succeed (or the farms that do not) that are able to hire/use immigrants? Or is there no relationship between these two developments at the farm level? The purpose of this

\footnotetext{
${ }^{1}$ The National Agricultural Workers Survey (NAWS), www.doleta.gov/agworker/naws.cfm.

2 The United States Department of Agriculture, www.usda.gov.
} 
paper is to take a first step towards answering these questions. This, however, requires comprehensive farm-level data about the composition of employment at the individual farm, and such data are rarely available. Fortunately, we have access to a unique linked employeremployee dataset for the entire population of farm establishments and workers in the Danish agricultural sector over a 30-year period, from 1980 to 2008.

Theoretically, we can imagine at least three different situations. First, immigrants could simply represent an aggregate supply shift, with immigrants taking up a larger share of the total labor supply in the agricultural sector but with no farm-level relationship between the employment of immigrants and farm performance.

Second, immigrants may constitute a cheap and/or a more flexible source of labor that benefits the individual farm. It is thus well known from other studies that immigrants receive lower wages. This is the case both within agriculture and within other sectors of the economy; see, e.g., Card (2005). While part of the lower wage may reflect a lower effective labor input of the immigrant, part of it is also likely to reflect more limited outside options for immigrant workers, such as limited employment opportunities in other sectors of the economy, making them a cheaper source of labor; see, e.g., Malchow-Møller et al. (2012). This could in turn improve performance, as measured by, e.g., profit and scale, for farms with access to immigrant labor. ${ }^{3}$

Third, it could also be the case that only certain types of farms are able to or willing to hire immigrants, and that these are also the more (or less) successful farms. The existence of fixed and sunk costs of hiring immigrants (a change of working language, attitudes etc.), which may vary across farms, and/or the fact that immigrants cannot manage all functions at

\footnotetext{
${ }^{3}$ Related to this, Devadoss and Luckstead (2008) have argued that immigrants may also provide complementary input to capital and educated (native) labor. This could be in the form of, e.g., knowledge about different production techniques and foreign markets.
} 
a farm may imply that it requires a farm of a certain type or size (or with a certain location) to employ immigrant labor, and these farms may at the same time perform better (or worse) than other farms. In the case of such selection effects, the causality runs from (unobserved) farm characteristics to the employment of immigrants.

The second and third possibilities are, of course, not mutually exclusive. It could well be that immigrants are only hired by certain types of farms and that they subsequently affect the performance of these farms. The purpose of the present paper is to provide some first evidence on the importance of these different possibilities.

Specifically, we ask the following questions in the paper: (i) Are farms that employ immigrants different from other farms? (ii) What is the relationship between a more intensive use of immigrants and farm performance? and (iii) Does this reflect a causal effect of the immigrants?

We answer these questions in the following way. First, we set up a simple theoretical model to illustrate the three theoretical possibilities above. The model is used to guide the subsequent empirical analysis. Second, we compare key characteristics of farms that employ immigrants to farms that do not employ immigrants to establish whether any differences exist. To the best of our knowledge, this has not been done systematically before. Third, we estimate the relationship between the use of immigrants, on the one hand, and farm performance, on the other hand. We use several different measures of farm performance, including job creation, survival, revenue and labor productivity. To control for potential endogeneity of the immigrant variable, we use regressions in first differences as well as instrumental variables. This allows us to take a first step towards disentangling any causal effects of the immigrants from pure selection effects.

To preview our results, we find that farms with immigrant workers are larger in terms of employees, revenue and value added - and at least as productive as other farms. 
Furthermore, an increased use of immigrants - especially immigrants from Eastern Europe and less developed countries (LDCs) - is associated with increases in total employment and revenue. Our IV estimations indicate that at least part of these increases reflect a causal effect of the immigrants. However, the expansionary effects are quantitatively modest and shortlived, possibly because the persistence in the use of immigrant labor at the individual farm is low. As the effects are strongest for the lowest paid immigrants, and since native employment (especially unskilled native employment) is reduced, and labor productivity remains unaffected by the employment of immigrants, our findings seem to support the idea that immigrants constitute a cheaper source of labor that can substitute for (unskilled) native workers, thereby reducing the (marginal) costs of labor for farms and allowing them to expand.

In the literature, there are several studies of the more aggregate/general effects of immigration, in particular the effects on wages and employment of native workers. Most of these analyses focus on the wage or net employment consequences for groups of individuals (regions, industries or skill groups) following an increase in the supply of immigrant workers. Examples of such analyses are Card (1990, 2001, 2005), Borjas et al. (1997), Pischke and Velling (1997), Borjas (2003, 2006), Angrist and Kugler (2003), Dustmann et al. (2005), Ottaviano and Peri (2012) and Aydemir and Borjas (2007). There is substantial variation in the consequences of immigration found in these studies. In Longhi et al. (2005, 2006), the results from a large number of analyses are compared and the authors conclude that in general there is a small negative employment and/or wage effect for native workers of immigration.

Within agricultural economics, there has been an increasing focus on the importance of immigrant workers, and Partridge et al. (2008) argue for potentially different effects of immigrants in this sector than in the rest of the economy. However, the number of studies 
focusing explicitly on the agricultural sector is much more limited, and existing studies of immigrants in agriculture have typically relied on either aggregate data or relatively small samples of households, which do not allow them to address the above issues; see, e.g., Taylor and Martin (1997, 2003) and Devadoss and Luckstead (2008).

Estimating a simultaneous equations model on data from Californian towns, Taylor and Martin (1997) find evidence of a circular relationship between immigration and farm employment. An increase in the number of foreign-born people increases farm employment; and an increase in farm employment also raises immigration. A similar finding is reported in Taylor and Martin (2003). See also Martin and Taylor (1998) and Taylor and Martin (2001) for summaries of these studies.

Based on a calibration exercise, Devadoss and Luckstead (2008) have more recently argued that an increase in the use of immigrant workers in California vegetable production actually has a very small negative effect on native employment in that sector. Related to this, Venturini (1999) finds some evidence of displacement as an increase in the number of illegal immigrants working in the Italian agricultural sector is found to reduce the number of natives employed in the sector.

The rest of the paper is structured as follows. In Section 2, we present our theoretical model. Based on this, we lay out the empirical strategy in Section 3. Section 4 describes the data used in the paper and presents some descriptive statistics, while Section 5 contains the results of the empirical analysis. Section 6 concludes.

\section{Theory}

If immigrants are identical to native workers, an increase in the number of immigrant workers in the agricultural sector is similar to a general labor supply increase. In this case, we would expect no farm-level relationship between the use of immigrants and performance. The 
purpose of this section, however, is to illustrate why the use of immigrants and farm performance may be correlated and how this may reflect a causal effect of the immigrants and/or farm-specific factors that influence both the use of immigrants and farm performance.

To illustrate the different theoretical possibilities, let profit by farm $i$ be given by:

$$
\pi_{i}=f_{i}\left(L_{i}^{N}, L_{i}^{F}\right)-C^{N}\left(L_{i}^{N}\right)-C_{i}^{F}\left(L_{i}^{F}\right)
$$

where $f_{i}\left(L_{i}^{N}, L_{i}^{F}\right)$ is the production function of farm $i$, and $L_{i}^{N}$ and $L_{i}^{F}$ are the inputs of native and foreign (immigrant) labor, respectively. $C^{N}\left(L_{i}^{N}\right)$ is the cost of native labor, and $C_{i}^{F}\left(L_{i}^{F}\right)$ is the potentially farm-specific cost associated with foreign labor. Note that in addition to the direct wage costs, these cost functions may include a fixed component, reflecting, e.g., search and hiring costs, and they may also exhibit increasing marginal costs due to, e.g., a limited local supply of labor or search frictions.

If immigrants and natives are perfect substitutes and associated with the same cost, the profit function reduces to: $\pi_{i}=f_{i}\left(L_{i}\right)-C\left(L_{i}\right)$. In this case, immigrants simply represent a shift in the supply of labor with no farm-level relationship between the use of immigrants and performance. This corresponds to the first possibility mentioned in the introduction.

A causal effect of immigrants on farm performance may arise for at least two different reasons. First, immigrants may constitute a cheaper source of labor than natives for some farms, and these farms can then use immigrant labor to reduce their total costs. This will be the case on farm i if $C^{N}\left(L_{i}^{*}\right)>C_{i}^{F}\left(L_{i}^{F *}\right)+C^{N}\left(L_{i}^{*}-L_{i}^{F *}\right)$ where $L_{i}^{*}$ is the optimal input of labor when only native workers are used, and where $L_{i}^{F *} \in\left(0, L_{i}^{*}\right]$ is chosen to minimize $C_{i}^{F}\left(L_{i}^{F}\right)+C^{N}\left(L_{i}^{*}-L_{i}^{F}\right)$. In this case, access to immigrant labor will increase profit on farm $i$, and possibly also total employment. The latter requires that the marginal cost of labor is also reduced, i.e., that $C^{N^{\prime}}\left(L_{i}^{*}\right)>C_{i}^{F^{\prime}}\left(L_{i}^{F *}\right)$. Native labor, on the other hand, may be negatively affected (crowded out) by the employment of immigrants. 
Second, immigrants may constitute a more flexible type of labor that complements native skills. This requires a positive cross derivative in the production function of farm $i$, $f_{i, 12}^{\prime \prime}>0$. In this case, labor productivity, profits and employment (total as well as native) may be positively affected by access to immigrant labor.

As the cost of using immigrant labor is likely to vary both over farms and over time, only some farms will find it attractive to hire (or to start hiring) immigrants. As an example, geographical differences as well as differences in language skills and attitudes towards immigrants may imply different hiring costs for different farms. Furthermore, a limited and varying local supply of immigrant labor may imply that the marginal costs of using immigrants may also be higher at some farms than at other farms, and they may vary over time due to randomness and frictions in the search process, and because the general access to immigrant labor changes. As a result, we would only expect some farms to use (or to start/stop using) foreign labor, creating an observed positive causal relationship between the use of immigrants and farm performance across farms and time.

An observed (positive) relationship between immigrants and performance may also arise for non-causal reasons. First, assume that there is a fixed cost of hiring immigrants, e.g., due to language barriers, i.e., $C_{i}^{F}$ contains a term, $c_{0} \cdot I\left(L_{i}^{F}>0\right)$, that is strictly positive but only included when $L_{i}^{F}>0$. Furthermore, assume that the production function contains a farm-specific productivity (or scale) parameter, $A_{i}$, that impacts on optimal farm size: $f_{i}\left(L_{i}^{N}, L_{i}^{F}\right)=f\left(A_{i}, L_{i}^{N}, L_{i}^{F}\right)$ where $f_{12}^{\prime \prime}>0$ and $f_{13}^{\prime \prime}>0$. In this set-up, farms with high values of $A_{i}$ will be larger (everything else equal) and therefore also more likely to find it optimal to incur the fixed cost of hiring immigrants. At the same time, these farms will also be more productive and more profitable. As a consequence, we will observe a positive correlation between the use of immigrants and farm performance even if the only difference between 
immigrants and natives is that part of the cost of using immigrants is in the form of a fixed cost.

Second, assume that instead of containing a fixed element, the cost of using foreign labor, $C_{i}^{F}\left(L_{i}^{F}\right)$, is correlated with farm productivity, $A_{i}$. Then a non-causal relationship between the use of immigrants and farm performance may also emerge. This could be the case if, e.g., certain types of farms or certain subsectors, such as nurseries, find it easier to use foreign labor, perhaps because tasks are more standardized here, and these farms/subsectors are at the same time the more (or the less) productive/profitable ones.

As noted in the introduction, the different possibilities are, of course, not mutually exclusive. Thus, we could easily imagine a situation in which some of the less productive (or less advanced) farms in general have lower costs of using immigrants, but that the use of immigrants improve their performance compared to similar farms. ${ }^{4}$

\section{Empirical Strategy}

The theoretical model of the previous section implies that if immigrants have a causal effect on performance, we should in general expect farms with a larger share of immigrants to perform better. These farms have lower costs and/or are better able to exploit the complementarities between native and immigrant labor. Hence, the theoretical model suggests an empirical approach where farm performance is regressed on the share of immigrants in farm employment.

However, the theoretical section also stressed that unobserved farm-specific factors $\left(A_{i}\right)$ may be correlated with both performance and the immigrant share, thereby giving rise to

\footnotetext{
${ }^{4}$ In principle, we can also imagine a negative causal effect of immigrants. If the costs of using native labor are also firm specific (reflecting, e.g., local supply conditions), then some firms may be "forced" to use the less productive/more expensive immigrant labor.
} 
a non-causal relationship between the share of immigrants and farm performance, i.e., an omitted-variable bias in a regression of farm performance on the immigrant share. To deal with this problem, we can use fixed effects (FE) and/or regressions in first differences (FD). We shall rely on the latter approach, regressing changes in farm performance on changes in the immigrant share. In both cases, however, the effect of immigrants will be identified from changes over time within farms. In other words, the idea behind our identification strategy is that changes over time in the farm-specific cost of using immigrants - possibly as a result of an improved (or more limited) access to immigrant labor - will lead some farms to use more (or less) immigrants, and this will in turn affect the performance or outcome of these farms.

To reduce measurement error and yearly noise, we use 4-year differences of the variables of interest. Furthermore, as some of the effects may take time to materialize, long differences may also better capture the true effects. Hence, our basic empirical specification looks like:

$$
\Delta P_{i t}=\beta_{0}+\beta_{1} \cdot \Delta I m m_{i t}+\varepsilon_{i t}
$$

where $\Delta P_{i t}$ is a measure of the change in performance (or outcome) of farm $i$ between year $t$ and year $t+4, \Delta \mathrm{Imm}_{i t}$ is the change in the share of immigrants in employment at farm $i$ between $t$ and $t+4$, and $\varepsilon_{i t}$ is the error term. In some of the analyses, we also consider the change in performance between $t$ and $t+8$.

Estimation of (1) may still suffer from an omitted variable bias if unobserved (demand and supply) shocks affect both changes in farm performance and changes in the immigrant share. An example could be an increase in the world-market price of pork, which increases farm profit and the demand for additional labor. If the marginal cost of hiring immigrants is lower than the marginal cost of hiring natives, e.g., because it becomes worthwhile to incur the fixed cost of hiring immigrants, this will cause both an increase in 
performance and an increase in the use of immigrants for some farms - without any underlying causal effect of the immigrants.

To deal with this possibility, we do several things. First, we include dummy controls for each combination of sub-sector, region and year. This is done to capture the effects of any region- and/or sub-sector-specific shocks to supply and demand (including any businesscycle effects). We also include a number of initial (i.e., at time $t$ ) farm characteristics, such as age and size of the farm as well as the average experience and tenure of its employees, to proxy for exposure and responsiveness to shocks. Third, we include farm-fixed effects in some regressions, which remove any farm-specific trends in performance from the data.

The resulting empirical specification then looks like:

$$
\Delta P_{i t}=\beta_{0}+\beta_{1} \cdot \Delta \operatorname{Imm}_{i t}+\beta_{2} \cdot X_{i t}+\eta_{r s y}+\mu_{i}+\varepsilon_{i t}
$$

where $X_{i t}$ is a vector of observable farm characteristics at time $t, \eta_{r s y}$ represents the dummies for each combination of region (r), sub-sector (s) and year (y), and $\mu_{i}$ is an unobserved time-invariant, farm-specific trend in performance.

Still, there is a risk that unobserved non-permanent farm-specific shocks may affect both changes in farm performance and changes in the immigrant share, and that these are not picked up by the included controls in (2). An example could be an exogenous invention or a change in management practices that causes a farm to switch crops temporarily changing both the performance and the demand for additional labor.

To deal with this possibility, we try to instrument the change in the immigrant share between $t$ and $t+4$ using two types of instruments. First, we use historical shares of immigrants from different countries (or groups of countries) of origin (see next section) in farm employment to allocate subsequent inflows of immigrants at the aggregate level to the individual farms. More precisely, the instrument for $\Delta I m m_{i t}$ is constructed as:

$$
\sum_{g=1}^{G} \mathrm{imm}_{g i t-s} \cdot \Delta A g g E m p l_{g t}
$$


where $\mathrm{imm}_{\text {git-s }}$ is the share of immigrants from country (group) $g$ in employment at farm $i$ at time $t-s$, and $\Delta A g g E m p l_{g t}$ is the absolute nationwide or regional change in employment of immigrants from country (group) $g$ in the agricultural sector between $t$ and $t+4$. The idea behind this instrument is that farms that have historically used immigrants in their workforce have lower marginal costs of employing additional immigrants of similar or related origin, and that the employment of additional immigrants from a given area is easier/cheaper in periods with a large inflow from that area at the aggregate level. Similar types of instruments have previously been used by, e.g., Card (2001) and Cortes (2008) to instrument the regional shares of immigrants. ${ }^{5}$

Second, we simply use the lagged share of immigrants in farm employment, $i m m_{i t-s}$, as an instrument for $\Delta I m m_{i t}$. This is a common strategy in models in first differences; see Wooldridge (2002). The idea behind this instrument in the current context is a "reversion-towards-the-mean" argument. The agricultural sector (and the Danish economy more generally) is characterized by a high degree of job turnover. Hence, farms with an "above average” share of immigrants are likely to see their shares reduced (relative to other farms) in the future, simply because some of the immigrants quit (and possibly return home). If the cost of hiring new immigrants to replace the old ones varies over time for the individual farm, reflecting, e.g., the current local supply and/or randomness/frictions in the search process, some of these farms may not in the short run be able to find a new immigrant worker

\footnotetext{
${ }^{5}$ In the analyses in Section 5, we use both individual origin countries and groups of origin countries in the construction of the instrument in (3), since an employer using immigrants from, e.g., Poland may also see his/her marginal costs of using immigrants from neighboring countries reduced, as (s)he then knows how to recruit workers from that area and has changed the organization of the farm to accommodate these workers. We also use the individual terms in (3) to instrument the changes in the shares of immigrants from different groups of origin countries.
} 
to replace the one who left, thereby creating a negative correlation between the historical share and the subsequent change in the share of immigrants.

The instruments above are valid as long as we do not observe temporary shocks that affect both the immigrant share $s$ years in advance and the change in performance between $t$ and $t+4$, and which are not picked up by the included controls in (2). The larger we choose $S$, the smaller this risk is likely to be. ${ }^{6,7}$

As our dependent variable, we use a range of different measures of changes in performance: Job creation and survival, as well as growth in revenue and labor productivity (VA/L). As we do not have any measures of capital and land at the farm level, we cannot construct a profit measure or a measure of total factor productivity. In order to analyze whether immigrant labor complements or substitutes for different types of native labor, we also consider the effects on native job creation (both skilled and unskilled) as well as on the wages of individual native co-workers.

\section{The Data}

We use data from the Integrated Database for Labor Market Research (IDA) compiled by Statistics Denmark. The IDA contains annual register data for the period 1980-2008 at the individual level regarding labor-market status and performance (employment, wages, etc.) and personal background characteristics such as age, education, immigrant status and family

\footnotetext{
${ }^{6}$ Alternatively, we could use pre-sample shares of immigrants rather than shares in $t-s$ in the construction of the first instrument. This would increase the validity of the instrument. However, given the length of our sample period and the very limited number of immigrants in the beginning of the sample, such an instrument would become very weak.

${ }^{7}$ Note that since the instruments are constructed from lagged values of the immigrant share, we do not simultaneously include the farm-fixed effects, $\mu_{i}$, in the IV regressions, as the demeaned error term in a FE regression will be correlated with lagged values of the regressors; see, e.g., Wooldridge (2002).
} 
characteristics. Wage and employment information in the IDA concerns primary employment in the last week of November each year. Furthermore, all wage workers are linked to an establishment in the IDA, and both individuals and establishments are tracked over time. From the IDA, we draw our "sample" containing all individuals in a given year with primary employment in the agricultural sector, defined as establishments with NACE Rev. 2 codes between 01.11 and 01.50 .

Since individual workers are linked to establishments and because the data cover the population of workers and establishments, we can aggregate individual data at the establishment level and use this information about the establishment (e.g. the number of immigrants and natives employed as well as the average wage, experience, tenure and education of the employees) both at the establishment level and at the individual level. The establishment level information also includes the region and age of the farm and a detailed industry classification that allows us to distinguish between four sub-sectors: Arable farming, Livestock and mixed enterprises, Horticulture, and Other types of farming.

Furthermore, from 1998 establishments are linked to firms (the legal unit). This provides us with information about revenue and value added (calculated as the difference between revenue and purchases of goods and services) at the firm level for the years 19982008.

Immigrants are defined as persons born outside Denmark by non-Danish parents, i.e., parents who do not have Danish citizenship or were born outside Denmark themselves. If no information about the parents is available, an individual born outside Denmark is considered as an immigrant. Consequently, all individuals born in Denmark are considered to be native Danes, irrespective of the status of their parents, just as all individuals born abroad who have at least one Danish parent are considered as Danes. This definition also implies that immigrants include refugees and family reunified persons who have come to Denmark for 
non-job related reasons, as well as foreigners who have come to Denmark primarily to work. Note that the origin country of an immigrant is defined from the parents' countries of birth (or citizenship) whenever that information is available. That is, an immigrant born by Italian parents in Canada is considered Italian.

[Insert Figure 1 around here]

Traditionally, agriculture has been extremely important in Denmark, both in terms of GDP, employment and exports. Just after WW2, the agricultural sector was responsible for approximately $30 \%$ of the employment in Denmark. Figure 1 shows the development since 1980 in total employment as well as the number of wage workers in the Danish agricultural sector. The difference between the two curves is the number of self-employed, which includes both self-employed farmers working alone and self-employed with employees, i.e., those running a personally-owned establishment. From the Figure, we can see that while the number of wage workers has been relatively constant at a level around 30,000-40,000, the number of self-employed has been rapidly declining - from around 140,000 in 1980 to around 40,000 in 2008. This mirrors the trend towards fewer, but larger, farms as shown in Figure 2.

\section{[Insert Figure 2 around here]}

Even though the definition of establishments excludes farms without employees (i.e., farms run by a single self-employed individual), Figure 2 shows a sharp decline in the number of establishments, from around 20,000 in 1980 to below 11,000 in 2008. This also reveals that the majority of the 40,000 self-employed in 2008 do not have employees. Finally, Figure 2 also shows a significant increase in the average size of an establishment from less than 2.4 employees (excluding the owner) in 1980 to 3.7 employees in 2008.

Figure 3 also shows a pronounced increase in the use of immigrant workers in the agricultural sector, especially since the mid 1990s. Until then, the agricultural sector relied 
significantly less on immigrant workers than the economy in general. The share among wage workers in 1980 was $1.6 \%$ increasing slightly to around $2 \%$ in 1993 . After that, the use of immigrants in agriculture increased far more rapidly than in the rest of the economy. In 2008, immigrants thus made up $13 \%$ of the wage workers within agriculture, but only around $7 \%$ of the wage workers within the economy as a whole.

[Insert Figure 3 around here]

In analyzing the role of immigrants, we shall in some of the analyses below distinguish between three groups of origin countries for the immigrants: (i) Immigrants from Western Europe, the United States, Canada, Australia, New Zealand and Japan (we shall refer to these as "Western immigrants"); (ii) Immigrants from Eastern Europe, which includes Albania, Belarus, Bosnia and Herzegovina, Bulgaria, Croatia, Czech Republic, Estonia, Hungary, Latvia, Lithuania, Moldova, Montenegro, Poland, Republic of Macedonia, Romania, Russia, Serbia, Slovakia and Ukraine; and (iii) Immigrants from other (mainly less developed) countries, including Turkey and Pakistan as well as Asian and African countries (we shall refer to these as "LDC immigrants").

Whereas LDC immigrants have increased in relative importance among the immigrants over the last thirty years when considering the entire economy (due to an increased number of refugees and family-reunified persons), they constitute a smaller and decreasing share of the immigrants within agriculture as shown in Figure 4. Instead, the agricultural sector has seen a marked relative increase in the use of Eastern European immigrants from about 5\% in 1980 to about $75 \%$ of the immigrants in 2008 . Western immigrants have diminished their share among immigrant wage workers in agriculture and in the economy more generally, despite the fact that these immigrants have had more easy access to the Danish labor market than the other groups of immigrants, and the fact that the language barrier is likely to be smaller for this group than for the other two groups. 
[Insert Figure 4 around here]

This development suggests that the employment of immigrants within agriculture may have played a different role than in the rest of the economy, as also suggested by Partridge et al. (2008). The huge and increased concentration of Eastern European immigrants in the agricultural sector (even before the enlargement of the European Union in 2004 and 2007 which granted free access to the Danish labor market for workers from 10 Eastern European countries ${ }^{8}$ ) combined with the fact that wages in Eastern Europe are considerably lower than in Western Europe also indicate that these immigrants may have played a different role than other immigrants in the agricultural sector.

In order to take a first look at the farm-level evidence regarding the relationship between the use of immigrants and farm characteristics, Table 1 compares average key values of farms that employ immigrants to average key values of farms that only employ native workers for the years 1980, 1990, 2000 and 2008. As can be seen, establishments that use immigrant labor are significantly larger in terms of employees although this difference has become smaller over time. From the firm-level data, we can also see that total revenue and value added have on average been much higher on farms employing immigrants in both 2000 and 2008. Revenue per employee was also higher in 2008, while the lower value-added per employee can almost completely be explained by the larger concentration of farms with immigrants within Livestock and mixed enterprises, a sub-sector which in general experienced negative value added in $2008 .^{9}$ If farms with more employees are also more

\footnotetext{
${ }^{8}$ Before the enlargement of the European Union in 2004, it was possible for Danish firms to recruit Eastern European workers in sectors, such as agriculture, that experienced bottlenecks. Local occupation councils, in which both employers and employees were represented, decided whether the particular area had a bottleneck.

${ }^{9}$ As most farms are owned and run by a self-employed farmer, who is not included among the employees, revenue and value added per employee have been computed by increasing the number of employees by one to account for the labor input of the owner.
} 
labor-intensive (as opposed to land- or capital-intensive) than other farms, we should actually expect revenue and value added to be lower on larger farms - everything else equal. In light of this, and the fact that farms with immigrants have on average more than twice as many employees, the numbers for revenue and value added per employee seem to indicate that farms using immigrants are - on average - at least not less productive than farms not using immigrants. $^{10}$

\section{[Insert Table 1 around here]}

This conclusion is further supported by the fact that average wages of native workers have throughout the period been higher on farms that employ immigrants (although less so in the later years). Wages to immigrants, on the other hand, are significantly lower (except in 1980) - a difference that has increased over time. This is a first indication that immigrants constitute a cheaper source of labor, although controlling for differences in individual worker productivity, the effective wage of immigrants need not be lower, of course.

Furthermore, throughout the period, farms with immigrants have been more prevalent within Horticulture. In 1980 and 1990, the shares of employees with either a vocational or a higher education (we shall refer to these as "skilled workers") were also higher on farms that used immigrants than on other farms. However, this picture was reversed by 2008. Conversely, while there were no clear differences in average tenure and average experience between farms with and without immigrants up to 1990, farms employing immigrants exhibited considerably less average experience and average tenure among its employees in 2000 and 2008.

Table 2 compares the wages and educational levels of natives and the three different groups of immigrants considered in the paper. Note, however, that information on education

\footnotetext{
${ }^{10}$ Unfortunately, we do not have information on capital and land holdings that would allow us to construct a measure of profitability or total factor productivity at the farm level.
} 
and wages is missing for a large number of the immigrants. Immigrants with missing information about education are treated as unskilled in Table 2. Hence, the numbers should be interpreted with some caution. Still, among the immigrants, wages have since the 1990s been lowest for immigrants from Eastern Europe. In 2008, their average hourly wage was $20 \%$ lower than that of natives, while Western immigrants had a wage much closer to the natives wage. Back in 1980, only LDC immigrants had a lower wage than native workers. Immigrants from LDCs and, especially, Eastern Europe in general also tend to be less educated than natives in the more recent years. ${ }^{11}$

\section{[Insert Table 2 around here]}

In sum, farms with immigrant workers are both larger in terms of employees, revenue and value added - and also seem to be at least as productive as farms without immigrants. This is consistent both with a selection effect in the form of a fixed cost of employing immigrants (or even a negative correlation between this cost and farm scale/productivity) and with a positive causal effect of the immigrants. However, while the descriptive evidence reveals clear differences between the two types of farms, and between immigrants and natives, it cannot disentangle any causal effects from selection effects. We now turn to this issue.

\section{Immigrant Workers and Farm Performance}

In this section, we analyze the relationship between the employment of immigrants and farm performance in more detail by following the empirical strategy laid out in Section 3. In Section 5.1, we use our establishment-level data, which cover the entire period 1980-2008, to analyze the effects on short- and long-run job creation as well as establishment survival. In

\footnotetext{
${ }^{11}$ Another dimension of the importance of immigrants in the agricultural sector is their role as employers. Their share among the self-employed owners is still limited, but has been rising from 2.1\% in 2004 to $2.6 \%$ in 2008 .
} 
Section 5.2, we turn to our firm-level data, which “only” cover the period 1998-2008, to analyze the effects on revenue and labor productivity (measured as revenue and value added per employee). Finally, in Section 5.3, we consider the effects on native workers in order to determine how the immigrants complement or substitute for different types of native labor.

As the variables of interest in most regressions are defined as differences between $t$ and $t+4$, and as we need lagged variables to construct the instruments, we use $t=1984$, 1988, 1992, 1996, 2000 and 2004 in the establishment-level data, and $t=2000$ and 2004 in the firm-level data. In the long-run job-creation and survival analyses, the dependent variable is a difference between $t$ and $t+8$, in which case we need to drop $t=2004$ as well.

\subsection{Job Creation and Establishment Survival}

We start by analyzing the effects of employing immigrants on total job creation at the establishment level. We follow Davis and Haltiwanger (1992) and Davis et al. (1996) and define the net job-creation rate between $t$ and $t+4$ at establishment $i$ as:

$$
\Delta x_{i t+4}=\frac{X_{i t+4}-X_{i t}}{0,5\left(X_{i t+4}+X_{i t}\right)}
$$

where $X_{i t}$ is the employment at establishment $i$ in year $t$. An advantage of using this measure instead of a standard growth rate is that the range of $\Delta x_{i t+4}$ is bounded between -2 and 2, and hence prevents outliers. This is particularly relevant for small establishments where changes in employment can be large relative to the initial level.

Table 3 contains the results of estimating the empirical models in (1) and (2) using the net job-creation rate from (4) as the performance measure, $\Delta P_{i t}$.

[Insert Table 3 around here]

In columns 1 and 2, we present the results of estimating the stripped-down version of our empirical model from equation (1) using OLS, where the only explanatory variable used is the change in the immigrant share at establishment $i$ between $t$ and $t+4$. In the first 
column, we use the overall share of immigrants in employment, and in column 2, we distinguish between our three country groups of immigrants. While there is a significant positive relationship between the change in the overall share and the net job-creation rate in column 1, this relationship is found in column 2 to be driven by immigrants from Eastern Europe and LDCs, while there is no relationship between the change in the share of Western immigrants and the net job creation rate.

As argued in Section 3, the estimates in columns 1 and 2 may suffer from an omitted variable bias if unobserved shocks affect both the use of immigrants and overall job creation. In columns 3 and 4 , we therefore add dummies for each combination of year, sub-sector (4 categories) and region (3 categories) to capture any effects of region and subsector-specific shocks. We also add the following farm characteristics at time $t$ : age of the establishment (25 dummies), number of employees (11 dummies), average tenure of the employees, and average experience of the employees. As can be seen, this hardly affects the coefficient estimates to $\Delta i m m_{i t}$. Furthermore adding farm fixed effects (FE) in columns 5 and 6 to control for farm-specific trends does little to change this picture, although the estimates become slightly smaller numerically.

Finally, in columns 7-9, we implement the IV strategy described in Section 3 using two-stage least squares (2SLS). In column 7, we use both of the proposed instruments with $s$ $=2$, i.e., we use the immigrant share in $t-2$ to predict the change in the immigrant share between $t$ and $t+4$.

Unfortunately, our first instrument from equation (3) was found not to work. Although it had the expected sign in the first stage, the coefficient estimate was far from significant. We tried using different country groupings, different lags, and nationwide or regional inflows of immigrants into the agricultural sector, but without success. For the results reported in column 7, 33 country groups (the 10 most important countries plus a 
residual group within each of the three overall country groups) and nationwide inflows from these groups are used in the construction of the instrument.

A possible explanation for the weakness of the first instrument may be that relatively few farms have more than one immigrant among their employees (approximately $3.1 \%$ in 2000 and $13.3 \%$ in 2008 , corresponding to $30 \%$ and $48 \%$, respectively, of the farms with immigrants) and among these only around half of them also had immigrants employed six years earlier. This makes it difficult to predict increases in the immigrant share based on historical shares of immigrants at the farm level. ${ }^{12}$ In other words, most farms use very few immigrants (typically just one), and a large part of the increase in immigrant employment has thus taken place at the extensive margin, i.e., by an increase in the number of farms using immigrants. Furthermore, job-spells in the agricultural sector are relatively short, especially at farms using immigrants, as evidenced by the tenure values in Table 1 (less than two years on average).

This may also explain why the second instrument works much better with a negative (as expected) and significant coefficient in the first stage. Very similar (and more significant) first-stage results were obtained by using the immigrant share in $t-1$ (i.e., $s=1$ ), but as argued in Section 3, a smaller value of $s$ also increases the risk of invalidating the instrument. We therefore also tried using longer lags (which made the instrument weaker) and using several lags, but with similar results. Hence, in columns 8 and 9 and in the remainder of this paper, we use only the second instrument with $s=2$.

In column 8, the F-statistic from the first stage is 50 , which is well above the critical value of 10 suggested by Staiger and Stock (1997) and Stock and Yogo (2002) to avoid

\footnotetext{
${ }^{12}$ Another explanation may be that we eliminate much of the variation by including region $\mathrm{x}$ sub-sector $\mathrm{x}$ year fixed effects in the regressions.
} 
problems with weak instruments, while the three F-statistics corresponding to the three firststage regressions in column 9 vary between 4.1 and 18.2.

While the coefficients to the overall immigrant share in columns 7 and 8 are still positive and somewhat larger than before (0.22), the standard errors have also increased considerably, resulting in insignificant estimates in both columns (the t-values are around 1.22). But when we distinguish between the three origin groups of the immigrants (column 9), using the shares of each of these in $t-2$ as instruments, we find a significantly positive effect of immigrants from LDCs (it is also positive but insignificant in the case of Eastern European immigrants). ${ }^{13}$

Note that the IV estimate is numerically much larger than the non-IV estimate(s), but it also has a considerably higher standard error. Hence, we choose not to put too much emphasis on the precise value of the estimate, but interpret it as evidence supporting that the positive effects of employing (LDC and Eastern European) immigrants found in columns 1-6 at least partly reflect a causal effect of these on employment growth at the farm level, and that the effect may be quantitatively more important than suggested by the OLS estimates in columns $1-6 .{ }^{14}$ For the same reason, we do not necessarily interpret the difference in the IV

\footnotetext{
${ }^{13}$ This effect was confirmed in a 2SLS regression (not reported) where we only included the change in the share of LDC immigrants (and used its own lagged share as the instrument). Here the point estimate was slightly smaller and equally significant with a first-stage F-statistic around 23.

${ }^{14}$ A quantitatively larger estimate in IV regressions is not uncommon; see, e.g., Angrist and Pischke (2009). As an example, Angrist and Kugler (2003) find a similarly large difference between their OLS and IV estimates in an analysis of the employment effects of immigration. Another explanation for the quantitative difference between the OLS and IV estimates may be that the IV estimation retains only the variation in $\Delta i m m_{i t}$ generated by the instrument, $i m m_{i t-2}$, and hence spans a different type of variation than $\Delta i m m_{i t}$. As the instrument only captures why farms with an initially high share of immigrants experience a reduction in their share of immigrants (a negative $\Delta i m m_{i t}$ ) compared to other farms, the IV estimates reflect the effect of this on job
} 
results between LDC immigrants and immigrants from Eastern Europe as reflecting a difference in effects between the two types. The fact that LDC immigrants have been more constantly present throughout the period considered is likely to explain why the instrument works better in the case of these immigrants (as indicated by the first-stage F-statistics), and hence why the IV estimate is only significant in this case. Instead, we are led to conclude that the use of both LDC immigrants and Eastern European immigrants seem to have a positive causal effect on job creation. ${ }^{15}$ Finally, the IV estimations confirm that the use of Western immigrants (where the instrument is strongest in the first stage with a value of 18.2 for the Fstatistic) does not have any impact on the job creation rate (the point estimate is negative and insignificant).

Quantitatively, the estimates in columns 1-6 imply that an increase in the share of (Eastern European and/or LDC) immigrants of 10 percentage points is on average associated with a $1.5 \%$ increase in farm employment (measured relative to the average employment in $t$ and $t+4)$. Hence, effects are relatively modest, and the results indicate that the overall increase in employment takes place largely at the expense of native employment (we return to this issue below). Even if we take the IV estimate from column 9 at face value, the absolute effect is not numerically very large (11-12\% from a change of 10 percentage points in the LDC immigrant share), but just high enough to avoid an adverse effect on native employment.

creation, whereas the OLS estimate also captures the effects of increases in the immigrant share. If the negative employment effect of losing an immigrant worker is quantitatively larger than the positive employment effect of hiring an immigrant worker, this may explain part of the difference between the OLS and IV estimates.

${ }^{15}$ We also estimated the regressions in Table 3 separately for each of the four sub-sectors. While the results in columns 1-6 were rather robust across sectors, significant IV results were only found within Horticulture, which is not surprising given that the vast majority of LDC immigrants have been concentrated in Horticulture. However, also the overall share of immigrants was found to impact significantly in this case. 
Thus, overall, the results in Table 3 seem to support the idea that the employment of immigrants may have a positive causal effect on farm performance as measured by employment growth. In particular, positive effects seem to be associated with the use of immigrants from LDCs and Eastern Europe. As these were also the low-wage immigrants (cf. Table 2), this supports the idea that these immigrants constitute a cheap source of labor that reduce the marginal (and average) cost of labor for farms with access to these types of immigrants (or farms that have overcome the fixed cost of using these immigrants), and hence causes them to expand. The fact that the increase in employment seems to take place largely (or at least partly) at the expense of native labor (unless we take the IV estimate for LDC immigrants at face value) further indicates that these immigrants substitute for rather than complement native labor. We return to a more detailed analysis of this in Section 5.3 below. Immigrants from Western Europe, on the other hand, receive wages much more comparable to those of natives (Table 2) and hence do not reduce the marginal cost of labor. Therefore, we do not observe any positive effects on job creation in this case.

To investigate whether there are also more "long-run" effects of employing immigrants, Table 4 considers the effects on job creation between $t$ and $t+8$ from a change in the immigrant share between $t$ and $t+4$. Otherwise, the empirical model and the explanatory variables are exactly as in Table 3. The columns in Table 4 also correspond to the columns in Table 3 with the exception that we omit the column corresponding to column 7 from Table 3.

It is easily seen that the positive effects on job creation between $t$ and $t+4$ have disappeared by $t+8$. Actually, with FE included (columns 5 and 6), point estimates tend to become negative, but only marginally significant in one case. The closest to a significantly positive estimate is the IV estimate for LDC immigrants in column 8 with a t-value of 1.58 . Hence, it appears that the effect of immigrants on farm performance is rather short-lived. This 
fits well with the observation that average tenure is quite low. Hence, most of the immigrants hired between $t$ and $t+4$ will have left the farm by $t+8$, thereby removing the cost advantage again.

\section{[Insert Table 4 around here]}

We also estimated the model using establishment survival to $t+8$ (defined as a positive number of employees in $t+8$ ) as the dependent variable. ${ }^{16}$ Establishment survival vs. closure is a more clear manifestation of changes in farm performance than (small) changes in employment, but the results (not reported) were very similar.

In sum, the positive (but small) short-run effects on employment of hiring immigrants from LDCs and Eastern Europe disappear relatively quickly. This is fully consistent with the idea these immigrants provide a cost advantage, but that their employment is only temporary.

\subsection{Revenue and Labor Productivity}

Job creation and farm survival are not the only relevant dimensions of farm performance to consider. Ideally, we would like to use a profit measure and/or a measure of total factor productivity at the individual farm. Unfortunately, information on profit and capital is not available in the data. But for the period 1998 to 2008, we have measures of revenue and value added. Hence, in the following, we use the change in revenue as an alternative measure of farm growth, and revenue and value added per employee as measures of labor productivity.

Table 5 presents the results of estimating our empirical model in (2) on these data. The first four columns use the change in the log of total revenue between $t$ and $t+4$ as the dependent variable, whereas the next four columns use the change in the log of revenue per

\footnotetext{
${ }^{16}$ Note that the closure of an establishment need not imply farm closure, as the farm may, in principle, continue without workers employed. Unfortunately, our data do not allow us to control for this possibility.
} 
employee, and the last four columns use the change in value added per employee. Due to many negative observation of value added, we do not take logs in the latter case. ${ }^{17}$

[Insert Table 5 around here]

Columns 1 and 2 present the results with region $\mathrm{x}$ sub-sector $\mathrm{x}$ year dummies and farm controls included, while columns 3 and 4 contain IV estimates. ${ }^{18}$ As can been seen, an increase in the share of immigrants is associated with an increase in revenue (column 1). Not surprisingly, the effect can be ascribed to immigrants from Eastern Europe (column 2), which in the period considered increased from approximately 1,000 to 5,000 in total employment.

Quantitatively, revenue goes up by $0.8 \%$ if the share of Eastern European immigrants in employment increases from, e.g., 0 to 0.1 . This effect is similar to (although smaller than) the one found for job creation in Table 3, and thus supports the interpretation of the results from Section 5.1.

The IV results in columns 3 and 4 cannot confirm that this was due to a causal effect of the immigrants. Note, however, that the first-stage F-statistics are also considerably lower than in the establishment-level data in Table 3, indicating that the instruments work less well in this case. This can be explained by the shorter time period considered. ${ }^{19}$

\footnotetext{
${ }^{17}$ Furthermore due to the presence of many (extreme) outliers in the data, we omit observations within the highest and lowest percentile of one of the following variables: revenue, value added, revenue/employee and value added/employee (measured in both levels and in four-year changes).

${ }^{18}$ Estimates with farm-fixed effects included are not reported. With only two periods, 2000-4 and 2004-8, in the data, including these effectively reduces the number of observations used by more than $50 \%$.

${ }^{19}$ Remember also that the instrument is likely only to capture why farms with an initially high share of immigrants experience a reduction in their share compared to other farms. Hence, the instrument is unlikely to capture the main variation from the OLS estimation in columns 1 and 2, which is due to the large influx of Eastern-European immigrants in recent years.
} 
The following four columns consider the effects on revenue per employee as a first crude measure of productivity, while the last four columns use the change in value added per employee. Most estimates in columns 5-12 are negative but insignificant. Only the IV estimate in column 11 is marginally significantly negative at a $10 \%$ level. Hence, there are no signs of immigrants improving the productivity at the farm, as we would expect if immigrants were complementing native labor. Hence, these results also support the interpretation that (some) immigrants constitute a (cheaper) substitute for native labor. In this case, we would expect farm profitability and size to go up, but with no effects on labor productivity.

There may be at least three explanations behind the fact that the point estimates in columns 5-12 tend to be negative. First, given the large importance of land in agriculture $-\mathrm{a}$ factor which is often in fixed supply - we should expect most farms to exhibit DRTS and hence both measures of labor productivity to vary negatively with the amount of labor used (and hence with increases in the immigrant share according to the results from Table 3). Second, the possibility that the effective labor input of an immigrant worker is lower than that of a native worker would also imply that the measures of labor productivity should decrease with increases in the immigrant share (everything else equal). Third, the employment of cheap immigrant labor may lower the incentive to invest in capital, which in turn will show up as lower labor productivity.

In sum, the firm-level evidence reveals a small positive (possibly causal) effect on revenue, but no effects on labor productivity as measured by revenue and value added per worker. Both findings support the interpretation of the results from the job-creation analysis in Section 5.1, namely that especially LDC and Eastern European immigrants are used as a cheaper substitute for native labor. 


\subsection{Native Employment}

Above we found positive (short-run) effects of the employment of LDC and Eastern European immigrants on job creation and, to some extent, revenue growth. The fact that these types of immigrants are also those with the lowest wages compared to natives, and the fact that the employment growth took place largely at the expense of native labor, led us to conclude that these immigrants serve as a cheaper substitute for native labor that allow farms to increase their scale of production. This interpretation is also consistent with the absence of any effects on labor productivity.

Despite this general picture, it could well be the case that different types of native workers are affected differently. In this section, we therefore analyze how the employment and wages of skilled and unskilled native workers, respectively, are affected by the employment of immigrants at the farm.

Table 6 considers the employment effects on natives. Columns 1-4 contain the effects on total native job-creation (defined as the change in native employment between $t$ and $t+4$ relative to the average native employment in the two years) using exactly the same approach as in Table 3. These results confirm the findings from Table 3 (columns 1-6). Consistent with small or no effects on total job creation, we find large negative effects on native job creation in columns 1-2 of all three types of immigrants. ${ }^{20}$ That the effect is strongest for the Western immigrants is fully in accordance with the finding from Table 3 that there are no positive overall employment effects in this case.

[Insert Table 6 around here]

\footnotetext{
${ }^{20}$ A 10 percentage point increase in the immigrant share is on average associated with a decrease of $15 \%$ in native employment. Results with farm FE included are very similar to those in columns 1-2 but omitted to save space. This is also the case for the FE results corresponding to columns 5-6 and 9-10.
} 
The negative employment effect is confirmed in the IV regression in column 3 and for Western immigrants in column 4. That the IV estimate is only significant for Western immigrants can be explained in part by the stronger first stage in this case, but it is also consistent with the IV result from Table 3 where the positive effect of LDC immigrants on total job creation was strong enough to eliminate the adverse effect on native employment. IV estimates for Eastern European immigrants are still plagued by a weak first stage.

Columns 5-8 and 9-12 then look at the effects on skilled and unskilled native job creation, respectively, to investigate which natives that are replaced by the immigrants. It turns out that there are significant negative effects on both types of natives in the OLS regressions (columns 5-6 and 9-10), but the effects are much stronger for unskilled natives. This is supported by the IV regressions. Here, the effect on skilled labor becomes insignificant, while it remains significantly negative in the case of unskilled labor, except for the case of LDC immigrants in column 12. In sum, immigrants seem (mostly) to replace unskilled labor with more limited negative effects on skilled native employment.

To analyze the effects on the native co-workers who remain employed at the farm, we construct a data set at the individual level, and run the regression in (2), where the left hand side variable is replaced by the change in the (log) wage of a native co-worker at farm $i$ between $t$ and $t+4$, given that this workers was employed at the farm in both $t$ and $t+4$. The results of this exercise are presented in Table 7. Columns 1-4 consider the effects on skilled native co-workers, and columns 5-8 deal with unskilled native co-workers.

[Insert Table 7 around here]

While there are no significant effects on the wages of unskilled native labor, there seems to be a positive effect on the wages of skilled native co-workers from an increase in the share of LDC immigrants (column 2). The effect, however, is small (a 10 percentage point increase in the share of LDC immigrants in employment is associated with an increase 
in the wage of $0.9 \%$ ) and cannot be confirmed in the IV regressions (columns 3-4), possibly because the first stage is very weak. Still, it may be a weak indication that the skilled native workers who stay at the farm get a stake in the cost advantage obtained by substituting lowskilled native labor with immigrants, perhaps because the skilled native workers specialize in more complex (managerial) tasks when immigrants are employed as suggested by, e.g., Ottaviano et al. (2012).

In sum, the results of this section show that immigrants tend mostly to replace the unskilled native workers. The effects on skilled native employment are less negative or at best absent. Furthermore, the skilled native workers who remain employed at the farm may seem to get (a small) share in the cost advantage.

\section{Conclusion}

Many developed countries have experienced a marked increase in the use of immigrant workers in the agricultural sector. In Denmark, the share of immigrants has risen from 2\% in 1993 to $13 \%$ in 2008 - an increase which is largely due to an influx of Eastern European immigrants. At the same time, the agricultural sectors of developed countries have continued the structural transformation resulting in fewer but bigger and presumably more efficient farms.

In this paper, we have exploited very detailed matched employer-employee data for a period of almost 30 years to analyze the farm-level relationship between immigrant labor and performance. We found that farms that employ immigrant workers are indeed different from farms that do not use immigrants. They are larger in terms of employees, revenue and value added - and at least as productive.

Our empirical analysis revealed that farms that increase their share of immigrants especially immigrants from Eastern Europe and less developed countries - also tend to 
become larger in terms of employment and revenue. Furthermore, our instrumental variables regressions indicated that this was not just due to a selection effect in the sense that growing farm find it easier to employ immigrants (although this effect is likely also at play), but that immigrants also enable farms to grow.

Our theoretical model pointed to two potential explanations of this. Immigrants could constitute a cheaper/more flexible source of labor than native workers and hence reduce the marginal cost of labor, or they could bring in complementary skills that would boost productivity. The fact that the immigrants from LDCs and Eastern Europe are the lowest paid immigrants and that the employment growth took place largely (or at least partly) at the expense of native labor, and that it happened without any effects on labor productivity, lend most support to the former explanation. This is also consistent with the observation that effects are short-lived and disappear when the immigrants leave again. Finally, we found that immigrants tend mainly to substitute for unskilled natives while the effects on skilled natives are much less negative (or even absent).

The findings of the present paper thus indicate that immigrants may play an important role in the current transformation of the agricultural sector. Large and growing farms find it easier to use immigrants, and immigrants in turn reduce their costs.

An issue that we have only briefly touched upon in the present paper is the role of immigrant employers in the agricultural sector. These have also grown in recent years, and may find it even easier to make an efficient use of immigrants in their production. However, we leave that topic for future research. 


\section{References}

Angrist, J.D. and A.D. Kugler (2003): “Protective or Counter Protective? Labour Market Institutions and the Effects of Immigration on EU Natives”, Economic Journal, 113, F302F331.

Angrist, J.D. and J.-S. Pischke (2009): Mostly Harmless Econometrics. Princeton University Press, Princeton.

Aydemir, A. and G. Borjas (2007): “Cross-Country Variation in the Impact of International Migration: Canada, Mexico, and the United States”, Journal of the European Economic Association, 5, 663-708.

Borjas, G.J. (2003): “The Labor Demand Curve is Downward Sloping: Re-examining the Impact of Immigration on the Labor Market”, Quarterly Journal of Economics, 118, 13351374.

Borjas, G.J. (2006): “Native Internal Migration and the Labor Market Impact of Immigration”, Journal of Human Resources, 41, 221-258.

Borjas, G.J., R.B. Freeman, and L.F. Katz (1997): “How Much Do Immigration and Trade Affect Labor Market Outcomes?”, Brookings Papers on Economic Activity, 1, 1-90.

Card, D. (1990): “The Impact of the Mariel Boatlift on the Miami Labour Market”, Industrial and Labour Relations Review, 43, 245-257.

Card, D. (2001): “Immigrant Inflows, Native Outflows, and the Local Labor Market Impacts of Higher Immigration”, Journal of Labor Economics, 19, 22-64.

Card, D. (2005): “Is the New Immigration Really so Bad?”, Economic Journal, 115, F300F323.

Cortes, P. (2008): “The Effect of Low-Skilled Immigration on U.S. Prices: Evidence from CPI Data”, Journal of Political Economy, 116, 381-422. 
Davis, S.J. and J.C. Haltiwanger (1992): “Gross Job Creation, Gross Job Destruction and Employment Reallocation,” Quarterly Journal of Economics, 107, 819-863.

Davis, S.J., J.C. Haltiwanger, and S. Schuh (1996): Job Creation and Destruction, Cambridge: MIT Press.

Devadoss, S. and J. Luckstead (2008): “Contributions of Immigrant Farmworkers to California Vegetable Production”, Journal of Agricultural and Applied Economics, 40, 879-894.

Dustmann, C., F. Fabbri and I. Preston (2005): “The Impact of Immigration on the British Labour Market”, Economic Journal, 115, F324-F341.

Huffman, W.E. (2005): “Trends, Adjustments, and Demographics, and Income of Agricultural Workers”, Review of Agricultural Economics, 27, 351-360.

Kasimis, C. (2005): “Migrants in the Rural Economies of Greece and Southern Europe”, Migration Information Source, October, (http://www.migrationinformation.org).

Longhi, S., P. Nijkamp and J. Poot (2005): “A Meta-Analytic Assessment of the Effects of Immigration on Wages”, Journal of Economic Surveys, 19, 451-477.

Longhi, S., P. Nijkamp and J. Poot (2006): “The Impact of Immigration on the Employment of Natives in Regional Labour Markets: A Meta-Analysis”, IZA Discussion Paper No. 2044, Institute for the Study of Labor (IZA).

Malchow-Møller, N., J.R. Munch and J.R. Skaksen (2012): “Do Immigrants Affect FirmSpecific Wages?”, Scandinavian Journal of Economics, 114, 1267-1295..

Martin, P.L. and J.E. Taylor (1998): “Poverty Amid Prosperity: Farm Employment, Immigration, and Poverty in California”, American Journal of Agricultural Economics, 80, 1008-1014.

Meyer, B.D. (1990): “Unemployment Insurance and Unemployment Spells”, Econometrica, 58, 757-782. 
Ottaviano, G.I.P. and Peri, G. (2012): “Rethinking the Effects of Immigration on Wages”, Journal of the European Economic Association, 10, 152-197.

Ottaviano, G.I.P., G. Peri, and G.C. Wright (2012): “Immigration, Offshoring and American Jobs”, working paper.

Partridge, M.D., D.S. Rickman, and K. Ali (2008): "Recent Immigartion and Economic Outcomes in Rural America”, American Journal of Agricultural Economics, 90, 13261333.

Pischke, J.-S. and J. Velling (1997): “Employment Effects of Immigration to Germany: An Analysis Based on Local Labor Markets”, Review of Economics and Statistics, 79, 594604.

Staiger, D. and J.H. Stock (1997): “Instrumental Variables Regression with Weak Instruments”, Econometrica, 65, 557-586.

Stock, J.H. and M. Yogo (2002): “Testing for Weak Instruments in Linear IV Regression”, NBER Technical Working Paper 284.

Taylor, J.E. and P.L. Martin (1997): “The Immigrant Subsidy in US Agriculture: Farm Employment, Poverty and Welfare”, Population and Development Review, 23, 855-874.

Taylor, J.E. and P.L. Martin (2003): “Farm Employment, Immigration, and Poverty: A Structural Analysis”, Journal of Agricultural and Resource Economics, 28, 349-363.

Taylor, J.E. and P.L. Martin (2001): “Human Capital: Migration and Rural Population Change” in B.L. Gardner and G.C. Rausser (eds.), Handbook of Agricultural Economics, vol. 1, part 1, Elsevier Science, New York, 457-511.

Venturini, A. (1999): “Do Immigrants Working Illegally Reduce the Natives' Legal Employment? Evidence from Italy”, Journal of Population Economics, 12, 135-154.

Wooldridge, J.M. (2002): Econometric Analysis of Cross Section and Panel Data. MIT Press, Cambridge, Massachusetts. 


\begin{tabular}{|c|c|c|c|c|c|c|c|c|c|c|c|c|c|c|c|c|}
\hline & \multicolumn{8}{|c|}{ Farms without immigrants } & \multicolumn{8}{|c|}{ Farms with immigrants } \\
\hline & \multicolumn{2}{|c|}{1980} & \multicolumn{2}{|c|}{1990} & \multicolumn{2}{|c|}{2000} & \multicolumn{2}{|c|}{2008} & \multicolumn{2}{|c|}{1980} & \multicolumn{2}{|c|}{1990} & \multicolumn{2}{|c|}{2000} & \multicolumn{2}{|c|}{2008} \\
\hline & \# Obs & Mean & \# Obs & Mean & \# Obs & Mean & \# Obs & Mean & \# Obs & Mean & \# Obs & Mean & \# Obs & Mean & \# Obs & Mean \\
\hline \multicolumn{17}{|l|}{ Establishment-level data: } \\
\hline Number of employees & 19,085 & 2.094 & 16,541 & 2.400 & 11,338 & 2.643 & 7,821 & 2.544 & 454 & 13.551 & 592 & 10.657 & 1,326 & 8.662 & 3,027 & 6.138 \\
\hline Arable farming & 19,085 & 0.843 & 16,541 & 0.840 & 11,338 & 0.188 & 8,265 & 0.278 & 454 & 0.513 & 592 & 0.576 & 1,326 & 0.106 & 2,856 & 0.115 \\
\hline Livestock and mixed enterprises & n.a. & n.a. & n.a. & n.a. & 11,338 & 0.612 & 8,265 & 0.500 & n.a. & n.a. & n.a. & n.a. & 1,326 & 0.584 & 2,856 & 0.699 \\
\hline Horticulture & 19,085 & 0.080 & 16,541 & 0.070 & 11,338 & 0.065 & 8,265 & 0.054 & 454 & 0.284 & 592 & 0.299 & 1,326 & 0.204 & 2,856 & 0.109 \\
\hline Other types of farming & 19,085 & 0.077 & 16,541 & 0.090 & 11,338 & 0.135 & 8,265 & 0.168 & 454 & 0.203 & 592 & 0.125 & 1,326 & 0.106 & 2,856 & 0.077 \\
\hline Share of workers with vocational education & 19,085 & 0.135 & 16,541 & 0.206 & 11,338 & 0.349 & 7,821 & 0.430 & 454 & 0.240 & 592 & 0.292 & 1,326 & 0.295 & 3,027 & 0.272 \\
\hline Share of workers with higher education & 19,085 & 0.005 & 16,541 & 0.008 & 11,338 & 0.014 & 7,821 & 0.028 & 454 & 0.035 & 592 & 0.036 & 1,326 & 0.030 & 3,027 & 0.030 \\
\hline Average tenure of employees (years) & 0 & 0 & 16,541 & 1.880 & 11,338 & 2.441 & 7,821 & 3.311 & 0 & 0 & 592 & 1.713 & 1,326 & 1.623 & 3,027 & 1.701 \\
\hline Average experience of employees (years) & 19,085 & 4.515 & 16,541 & 6.194 & 11,338 & 8.387 & 7,821 & 11.921 & 454 & 4.662 & 592 & 5.836 & 1,326 & 5.381 & 3,027 & 5.774 \\
\hline Average hourly wage (Immigrants), DKK & n.a. & n.a. & n.a. & n.a. & n.a. & n.a. & n.a. & n.a. & 155 & 67.730 & 337 & 103.992 & 591 & 128.859 & 1,817 & 163.006 \\
\hline Average hourly wage (Danes), DKK & 4,294 & 60.462 & 10,266 & 98.550 & 8,643 & 133.012 & 6,645 & 180.220 & 271 & 65.407 & 411 & 106.312 & 821 & 139.992 & 1,952 & 183.439 \\
\hline Average hourly wage (All persons), DKK & 4,294 & 60.462 & 10,266 & 98.550 & 8,643 & 133.012 & 6,645 & 180.220 & 288 & 65.541 & 487 & 104.554 & 956 & 135.150 & 2,510 & 173.687 \\
\hline \multicolumn{17}{|l|}{ Firm-level data: } \\
\hline Revenue, DKK 1,000 & n.a. & n.a. & n.a. & n.a. & 10,857 & 3796.20 & 7,506 & 5254.4 & n.a. & n.a. & n.a. & n.a. & 1,257 & 6460.07 & 2,948 & 13957.2 \\
\hline Revenue/employees, DKK 1,000 & n.a. & n.a. & n.a. & n.a. & 10,857 & 1138.20 & 7,506 & 1547.0 & n.a. & n.a. & n.a. & n.a. & 1,257 & 886.72 & 2,948 & 1693.8 \\
\hline Value added, DKK 1,000 & n.a. & n.a. & n.a. & n.a. & 10,857 & 629.97 & 7,506 & 488.8 & n.a. & n.a. & n.a. & n.a. & 1,257 & 1446.21 & 2,948 & 1877.3 \\
\hline Value added/employees, DKK 1,000 & n.a. & n.a. & n.a. & n.a. & 10,857 & 164.13 & 7,506 & 101.8 & n.a. & n.a. & n.a. & n.a. & 1,257 & 143.92 & 2,948 & 3.2 \\
\hline
\end{tabular}

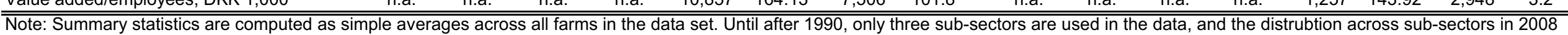
is based on data from 2007. By construction, tenure $=0$ in 1980. Value added is calculated as the difference between revenue and purchases of goods and services. Revenue/employees and value added/employees are constructed by adding 1 to the number of employees to account for the labor input by the owner. 


\begin{tabular}{|c|c|c|c|c|c|c|c|c|}
\hline & \multicolumn{2}{|c|}{1980} & \multicolumn{2}{|c|}{1990} & \multicolumn{2}{|c|}{2000} & \multicolumn{2}{|c|}{2008} \\
\hline & \# Obs & Mean & \# Obs & Mean & \# Obs & Mean & \# Obs & Mean \\
\hline \multicolumn{9}{|c|}{ Immigrants from Western Europe, USA, etc (group 1): } \\
\hline Share of workers with vocational education & 359 & 0.365 & 404 & 0.376 & 535 & 0.484 & 646 & 0.430 \\
\hline Share of workers with higher education & 359 & 0.089 & 404 & 0.064 & 535 & 0.088 & 646 & 0.094 \\
\hline Average hourly wage, DKK & 121 & 69.04 & 227 & 107.05 & 342 & 138.97 & 495 & 182.79 \\
\hline \multicolumn{9}{|l|}{ Immigrants from Eastern Europe (group 2): } \\
\hline Share of workers with vocational education & 99 & 0.273 & 142 & 0.317 & 1,074 & 0.137 & 5,223 & 0.070 \\
\hline Share of workers with higher education & 99 & 0.081 & 142 & 0.085 & 1,074 & 0.034 & 5,223 & 0.019 \\
\hline Average hourly wage, DKK & 29 & 72.07 & 49 & 107.63 & 235 & 122.77 & 2,207 & 157.36 \\
\hline \multicolumn{9}{|l|}{ Immigrants from other (LDC) countries (group 3): } \\
\hline Share of workers with vocational education & 251 & 0.143 & 282 & 0.202 & 664 & 0.202 & 525 & 0.271 \\
\hline Share of workers with higher education & 251 & 0.020 & 282 & 0.050 & 664 & 0.036 & 525 & 0.074 \\
\hline Average hourly wage, DKK & 62 & 61.74 & 174 & 99.38 & 396 & 125.98 & 391 & 171.06 \\
\hline \multicolumn{9}{|l|}{ Native workers: } \\
\hline Share of workers with vocational education & 45,404 & 0.176 & 45,175 & 0.263 & 39,174 & 0.400 & 33,594 & 0.478 \\
\hline Share of workers with higher education & 45,405 & 0.019 & 45,175 & 0.021 & 39,174 & 0.029 & 33,594 & 0.043 \\
\hline Average hourly wage, DKK & 13,785 & 64.50 & 27,261 & 108.98 & 27,899 & 145.45 & 27,702 & 194.96 \\
\hline
\end{tabular}

Note: Summary statistics are computed as simple averages across all individuals in the data set. 


\begin{tabular}{|c|c|c|c|c|c|c|c|c|c|}
\hline & \multicolumn{9}{|c|}{ Dependent variable: job-creation rate between $t$ and $t+4$} \\
\hline & (1) & $(2)$ & (3) & $(4)$ & $(5)$ & $(6)$ & $(7)$ & $(8)$ & $(9)$ \\
\hline & FD & FD & FD & FD & $\mathrm{FD}+\mathrm{FE}$ & $\mathrm{FD}+\mathrm{FE}$ & FD+IV & FD+IV & FD+IV \\
\hline $\begin{array}{l}\text { Change in total share of immigrants in farm } \\
\text { employment between } t \text { and } t+4\end{array}$ & $\begin{array}{l}0.1132 \\
(7.02)^{\star * *}\end{array}$ & & $\begin{array}{l}0.1054 \\
(7.56)^{\star * *}\end{array}$ & & $\begin{array}{c}0.0826 \\
(5.90)^{\star * *}\end{array}$ & & $\begin{array}{l}0.2193 \\
(1.22)\end{array}$ & $\begin{array}{l}0.2192 \\
(1.22)\end{array}$ & \\
\hline \multicolumn{10}{|l|}{$\begin{array}{l}\text { Change in share of immigrants between } t \text { and } \\
t+4 \text { from: }\end{array}$} \\
\hline Western Europe, USA, etc. (group 1) & & $\begin{array}{l}0.0064 \\
(0.25)\end{array}$ & & $\begin{array}{l}0.0125 \\
(0.59)\end{array}$ & & $\begin{array}{l}0.0146 \\
(0.74)\end{array}$ & & & $\begin{array}{c}-0.0788 \\
(-0.37)\end{array}$ \\
\hline Eastern Europe (group 2) & & $\begin{array}{l}0.1582 \\
(7.78)^{\star * \star}\end{array}$ & & $\begin{array}{l}0.1463 \\
(8.05)^{\star \star \star}\end{array}$ & & $\begin{array}{l}0.1128 \\
(5.93)^{\star \star \star}\end{array}$ & & & $\begin{array}{l}0.5396 \\
(1.24)\end{array}$ \\
\hline Other (LDC) countries (group 3) & & $\begin{array}{l}0.1439 \\
(2.96)^{\star \star \star}\end{array}$ & & $\begin{array}{l}0.1386 \\
(3.34)^{\star \star \star}\end{array}$ & & $\begin{array}{l}0.1230 \\
(2.90)^{\star \star \star}\end{array}$ & & & $\begin{array}{l}1.2096 \\
(3.10)^{\star \star \star}\end{array}$ \\
\hline Region $\mathrm{x}$ sub-sector $\mathrm{x}$ year dummies & No & No & Yes & Yes & Yes & Yes & Yes & Yes & Yes \\
\hline Farm controls & No & No & Yes & Yes & Yes & Yes & Yes & Yes & Yes \\
\hline Farm fixed effects & No & No & No & No & Yes & Yes & No & No & No \\
\hline Observations & 54,622 & 54,622 & 54,622 & 54,622 & 54,622 & 54,622 & 45,265 & 45,265 & 45,265 \\
\hline Number of establishments & 22,041 & 22,041 & 22,041 & 22,041 & 22,041 & 22,041 & 18,074 & 18,074 & 18,074 \\
\hline R-squared & 0.0015 & 0.0021 & 0.1905 & 0.1910 & 0.4906 & 0.4909 & 0.1799 & 0.1799 & 0.1549 \\
\hline
\end{tabular}

Note: Estimations are based on a panel of farm establishments from 1980-2008. Results above are for $t=1984,1988,1992,1996,2000$ and 2004 . Region $\times$ sub-sector $\times$ year dummies are

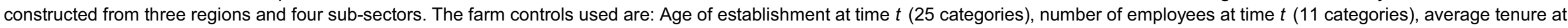

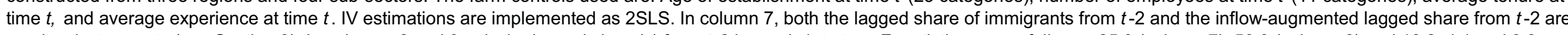
used as instruments (see Section 3). In columns 8 and 9 only the lagged share(s) from $t-2$ is used. 1st stage F-statistics are as follows: 25.0 (column 7), 50.0 (column 8 ) and 18.2, 4.1 and 9.8

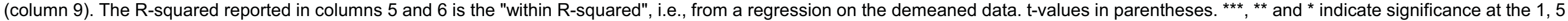
and $10 \%$ level, respectively. Standard errors are clustered at the establishment level to control for autocorrelation and heteroscedasticity. 


\section{Table 4: Employment of Immigrant Workers and Long-Run Job Creation}

\begin{tabular}{|c|c|c|c|c|c|c|c|c|}
\hline & \multicolumn{8}{|c|}{ Dependent variable: job-creation rate between $t$ and $t+8$} \\
\hline & (1) & $(2)$ & (3) & $(4)$ & $(5)$ & (6) & $(7)$ & (8) \\
\hline & FD & FD & FD & FD & FD+FE & $\mathrm{FD}+\mathrm{FE}$ & FD+IV & FD+IV \\
\hline $\begin{array}{l}\text { Change in total share of immigrants in farm } \\
\text { employment between } t \text { and } t+4\end{array}$ & $\begin{array}{c}0.0180 \\
(0.51)\end{array}$ & & $\begin{array}{l}0.0037 \\
(0.10)\end{array}$ & & $\begin{array}{l}-0.0617 \\
(-1.80)^{*}\end{array}$ & & $\begin{array}{l}0.0878 \\
(0.15)\end{array}$ & \\
\hline \multicolumn{9}{|l|}{$\begin{array}{l}\text { Change in share of immigrants between } t \\
\text { and } t+4 \text { from: }\end{array}$} \\
\hline Western Europe, USA, etc. (group 1) & & $\begin{array}{c}-0.0087 \\
(-0.17)\end{array}$ & & $\begin{array}{l}-0.0160 \\
(-0.30)\end{array}$ & & $\begin{array}{c}-0.0600 \\
(-1.20)\end{array}$ & & $\begin{array}{c}-0.3141 \\
(-0.48)\end{array}$ \\
\hline Eastern Europe (group 2) & & $\begin{array}{c}0.0357 \\
(0.70)\end{array}$ & & $\begin{array}{c}0.0141 \\
(0.27)\end{array}$ & & $\begin{array}{c}-0.0694 \\
(-1.36)\end{array}$ & & $\begin{array}{l}-0.7579 \\
(-0.32)\end{array}$ \\
\hline Other (LDC) countries (group 3) & & $\begin{array}{c}0.0363 \\
(0.42)\end{array}$ & & $\begin{array}{c}0.0254 \\
(0.30)\end{array}$ & & $\begin{array}{c}-0.0467 \\
(-0.53)\end{array}$ & & $\begin{array}{c}2.6009 \\
(1.58)\end{array}$ \\
\hline Region $x$ sub-sector $x$ year dummies & No & No & Yes & Yes & Yes & Yes & Yes & Yes \\
\hline Farm controls & No & No & Yes & Yes & Yes & Yes & Yes & Yes \\
\hline Farm fixed effects & No & No & No & No & Yes & Yes & No & No \\
\hline Observations & 47,525 & 47,525 & 47,525 & 47,525 & 47,525 & 47,525 & 39,287 & 39,287 \\
\hline Number of establishments & 20,221 & 20,221 & 20,221 & 20,221 & 20,221 & 20,221 & 16,531 & 16,531 \\
\hline R-squared & 0.0000 & 0.0000 & 0.0146 & 0.0146 & 0.3607 & 0.3607 & 0.0133 & -0.0150 \\
\hline
\end{tabular}

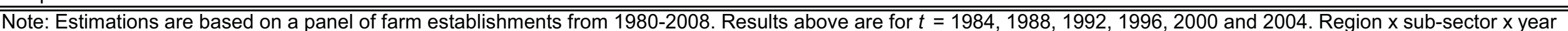

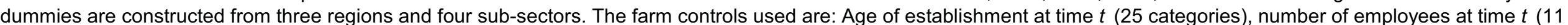

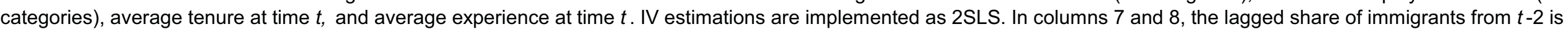
used as instrument (see Section 3). 1st stage F-statistics are as follows: 25.2 (column 7) and 13.1, 2.5 and 8.4 (column 8 ). The R-squared reported in columns 5 and 6 is the "within R-squared", i.e., from a regression on the demeaned data. t-values in parentheses. ${ }^{* * *},{ }^{* *}$ and * indicate significance at the 1,5 and $10 \%$ level, respectively. Standard errors are clustered at the establishment level to control for autocorrelation and heteroscedasticity. 


\begin{tabular}{|c|c|c|c|c|c|c|c|c|c|c|c|c|}
\hline & \multicolumn{4}{|c|}{ LHS: change in log(revenue) from $t$ to $t+4$} & \multicolumn{4}{|c|}{ LHS: change in log(revenue/employees) from $t$ to $t+4$} & \multicolumn{4}{|c|}{ LHS: change in value added/employees from $\mathrm{t}$ to $\mathrm{t}+4$} \\
\hline & (1) & (2) & (3) & (4) & (5) & (6) & (7) & (8) & (9) & (10) & (11) & (12) \\
\hline & $\mathrm{FD}$ & $\mathrm{FD}$ & $\mathrm{FD}+\mathrm{IV}$ & $F D+I V$ & $\mathrm{FD}$ & FD & $\mathrm{FD}+\mathrm{IV}$ & $\mathrm{FD}+\mathrm{IV}$ & FD & FD & $F D+I V$ & $F D+I V$ \\
\hline $\begin{array}{l}\text { Change in total share of immigrants in farm } \\
\text { employment between } t \text { and } t+4\end{array}$ & $\begin{array}{c}0.0696 \\
(4.52)^{* * *}\end{array}$ & & $\begin{array}{c}0.1258 \\
(0.56)\end{array}$ & & $\begin{array}{c}-0.0242 \\
(-1.40)\end{array}$ & & $\begin{array}{c}-0.0621 \\
(-0.26)\end{array}$ & & $\begin{array}{c}-20.869 \\
(-1.01)\end{array}$ & & $\begin{array}{l}-478.105 \\
(-1.70)^{*}\end{array}$ & \\
\hline \multicolumn{13}{|l|}{$\begin{array}{l}\text { Change in share of immigrants between } t \text { and } \\
t+4 \text { from: }\end{array}$} \\
\hline Western Europe, USA, etc. (group 1) & & $\begin{array}{c}0.0290 \\
(0.99)\end{array}$ & & $\begin{array}{c}-0.1357 \\
(-0.46)\end{array}$ & & $\begin{array}{c}-0.0070 \\
(-0.21)\end{array}$ & & $\begin{array}{c}-0.1143 \\
(-0.37)\end{array}$ & & $\begin{array}{c}-26.171 \\
(-0.56)\end{array}$ & & $\begin{array}{l}-495.673 \\
(-1.35)\end{array}$ \\
\hline Eastern Europe (group 2) & & $\begin{array}{c}0.0813 \\
(4.71)^{\star * *}\end{array}$ & & $\begin{array}{c}0.4093 \\
(1.11)\end{array}$ & & $\begin{array}{c}-0.0253 \\
(-1.29)\end{array}$ & & $\begin{array}{c}0.1460 \\
(0.42)\end{array}$ & & $\begin{array}{c}-23.928 \\
(-1.00)\end{array}$ & & $\begin{array}{c}-518.480 \\
(-1.21)\end{array}$ \\
\hline Other (LDC) countries (group 3) & & $\begin{array}{c}0.0506 \\
(0.87)\end{array}$ & & $\begin{array}{c}0.4499 \\
(1.33)\end{array}$ & & $\begin{array}{c}-0.0500 \\
(-0.76)\end{array}$ & & $\begin{array}{c}-0.6392 \\
(-1.50)\end{array}$ & & $\begin{array}{c}17.165 \\
(0.26)\end{array}$ & & $\begin{array}{c}-204.388 \\
(-0.54)\end{array}$ \\
\hline Region $\mathrm{x}$ sub-sector $\mathrm{x}$ year dummies & Yes & Yes & Yes & Yes & Yes & Yes & Yes & Yes & Yes & Yes & Yes & Yes \\
\hline Firm controls & Yes & Yes & Yes & Yes & Yes & Yes & Yes & Yes & Yes & Yes & Yes & Yes \\
\hline Observations & 13,277 & 13,277 & 10,451 & 10,451 & 13,277 & 13,277 & 10,451 & 10,451 & 13,289 & 13,289 & 10,458 & 10,458 \\
\hline Number of firms & 9,141 & 9,141 & 7,328 & 7,328 & 9,141 & 9,141 & 7,328 & 7,328 & 9,150 & 9,150 & 7,332 & 7,332 \\
\hline R-squared & 0.1037 & 0.1038 & 0.0783 & 0.0421 & 0.1416 & 0.1416 & 0.1509 & 0.1370 & 0.0145 & 0.0145 & -0.0269 & -0.0306 \\
\hline
\end{tabular}

Note: Estimations are based on a panel of firms from 1998-2008. Results above are for $t=2000$ and 2004. Revenue/employees and value added/employees are constructed by adding 1 to the number of employees to account for the labor input by the owner. Region $\mathrm{x}$ sub-sector $\mathrm{x}$ year dummies are constructed from three regions and four sub-sectors. The firm controls used are: Age of firm at time $t(16$ categories), number of employees at time $t$ (11 categories), average tenure at time $t$, and average experience at time $t$. IV estimations are implemented as $2 S L S$. In columns 3, 4, 7, 8, 11 and 12, the lagged share(s) of immigrants from t-2 is used as instrument(s) (see Section 3). 1st stage F-

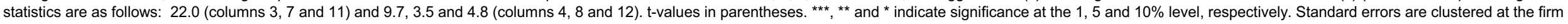
level to control for autocorrelation and heteroscedasticity. 


\begin{tabular}{|c|c|c|c|c|c|c|c|c|c|c|c|c|}
\hline & \multicolumn{4}{|c|}{ LHS: native job-creation rate from $t$ to $t+4$} & \multicolumn{4}{|c|}{ LHS: skilled native job-creation rate from $t$ to $t+4$} & \multicolumn{4}{|c|}{ LHS: unskilled native job-creation rate from $t$ to $t+4$} \\
\hline & (1) & (2) & (3) & (4) & (5) & (6) & (7) & (8) & (9) & (10) & (11) & (12) \\
\hline & $\mathrm{FD}$ & $\mathrm{FD}$ & $\mathrm{FD}+\mathrm{IV}$ & $\mathrm{FD}+\mathrm{IV}$ & $\mathrm{FD}$ & FD & $\mathrm{FD}+\mathrm{IV}$ & $\mathrm{FD}+\mathrm{IV}$ & $\mathrm{FD}$ & $\mathrm{FD}$ & $\mathrm{FD}+\mathrm{IV}$ & $\mathrm{FD}+\mathrm{IV}$ \\
\hline $\begin{array}{l}\text { Change in total share of immigrants in farm } \\
\text { employment between } t \text { and } t+4\end{array}$ & $\begin{array}{l}-1.6113 \\
(-104.27)^{\star \star \star}\end{array}$ & & $\begin{array}{l}-1.0441 \\
(-4.05)^{* \star \star}\end{array}$ & & $\begin{array}{c}-0.7494 \\
(-27.44)^{\star \star \star}\end{array}$ & & $\begin{array}{c}-0.0608 \\
(-0.17)\end{array}$ & & $\begin{array}{l}-1.3067 \\
(-53.70)^{\star \star \star}\end{array}$ & & $\begin{array}{l}-1.5227 \\
(-4.53)^{* * *}\end{array}$ & \\
\hline \multicolumn{13}{|l|}{$\begin{array}{l}\text { Change in share of immigrants between } t \text { and } \\
t+4 \text { from: }\end{array}$} \\
\hline Western Europe, USA, etc. (group 1) & & $\begin{array}{l}-1.6376 \\
(-62.72)^{* * *}\end{array}$ & & $\begin{array}{l}-1.3561 \\
(-4.72)^{* * \star}\end{array}$ & & $\begin{array}{l}-0.7020 \\
(-15.22)^{\star * \star}\end{array}$ & & $\begin{array}{c}-0.2907 \\
(-0.65)\end{array}$ & & $\begin{array}{l}-1.3222 \\
(-32.48)^{* \star \star}\end{array}$ & & $\begin{array}{l}-1.5729 \\
(-3.96)^{* \star \star}\end{array}$ \\
\hline Eastern Europe (group 2) & & $\begin{array}{l}-1.6314 \\
(-80.46)^{\star \star \star}\end{array}$ & & $\begin{array}{c}-0.6346 \\
(-0.90)\end{array}$ & & $\begin{array}{l}-0.8216 \\
(-23.82)^{\star \star \star}\end{array}$ & & $\begin{array}{c}1.0116 \\
(1.13)\end{array}$ & & $\begin{array}{l}-1.3064 \\
(-41.99)^{* \star \star}\end{array}$ & & $\begin{array}{l}-2.1536 \\
(-3.01)^{\star * \star}\end{array}$ \\
\hline Other (LDC) countries (group 3) & & $\begin{array}{c}-1.4519 \\
(-31.38)^{\star \star \star}\end{array}$ & & $\begin{array}{c}-0.0930 \\
(-0.17)\end{array}$ & & $\begin{array}{l}-0.5229 \\
(-7.85)^{\star \star \star}\end{array}$ & & $\begin{array}{c}-0.2527 \\
(-0.38)\end{array}$ & & $\begin{array}{l}-1.2696 \\
(-20.04)^{* \star *}\end{array}$ & & $\begin{array}{c}-0.5625 \\
(-0.99)\end{array}$ \\
\hline Region $\mathrm{x}$ sub-sector $\mathrm{x}$ year dummies & Yes & Yes & Yes & Yes & Yes & Yes & Yes & Yes & Yes & Yes & Yes & Yes \\
\hline Farm controls & Yes & Yes & Yes & Yes & Yes & Yes & Yes & Yes & Yes & Yes & Yes & Yes \\
\hline Farm fixed effects & No & No & No & No & No & No & No & No & No & No & No & No \\
\hline Observations & 54,622 & 54,622 & 45,265 & 45,265 & 54,622 & 54,622 & 45,265 & 45,265 & 54,622 & 54,622 & 45,265 & 45,265 \\
\hline Number of establishments & 22,041 & 22,041 & 18,074 & 18,074 & 22,041 & 22,041 & 18,074 & 18,074 & 22,041 & 22,041 & 18,074 & 18,074 \\
\hline R-squared & 0.3559 & 0.3562 & 0.3188 & 0.2811 & 0.0395 & 0.0398 & 0.0250 & -0.0191 & 0.1339 & 0.1340 & 0.1288 & 0.1133 \\
\hline
\end{tabular}




\begin{tabular}{|c|c|c|c|c|c|c|c|c|}
\hline & \multicolumn{8}{|c|}{ LHS: change in log(wage) from $t$ to $t+4$} \\
\hline & \multicolumn{4}{|c|}{ Skilled native workers } & \multicolumn{4}{|c|}{ Unskilled native workers } \\
\hline & (1) & $(2)$ & $(3)$ & (4) & (5) & $(6)$ & $(7)$ & (8) \\
\hline & FD & FD & FD+IV & FD+IV & FD & FD & FD+IV & FD+IV \\
\hline $\begin{array}{l}\text { Change in total share of immigrants in farm } \\
\text { employment between } t \text { and } t+4\end{array}$ & $\begin{array}{c}0.0132 \\
(0.72)\end{array}$ & & $\begin{array}{c}-0.1901 \\
(-0.51)\end{array}$ & & $\begin{array}{c}0.0365 \\
(1.53)\end{array}$ & & $\begin{array}{l}-0.0053 \\
(-0.02)\end{array}$ & \\
\hline \multicolumn{9}{|l|}{$\begin{array}{l}\text { Change in share of immigrants between } t \text { and } \\
t+4 \text { from: }\end{array}$} \\
\hline Western Europe, USA, etc. (group 1) & & $\begin{array}{c}-0.0288 \\
(-0.72)\end{array}$ & & $\begin{array}{c}0.2159 \\
(0.07)\end{array}$ & & $\begin{array}{c}0.0409 \\
(0.83)\end{array}$ & & $\begin{array}{c}-0.4922 \\
(-1.36)\end{array}$ \\
\hline Eastern Europe (group 2) & & $\begin{array}{c}0.0026 \\
(0.11)\end{array}$ & & $\begin{array}{l}1.6885 \\
(0.26)\end{array}$ & & $\begin{array}{c}0.0463 \\
(1.53)\end{array}$ & & $\begin{array}{c}0.8771 \\
(0.76)\end{array}$ \\
\hline Other (LDC) countries (group 3) & & $\begin{array}{l}0.0860 \\
(2.47)^{\star \star}\end{array}$ & & $\begin{array}{c}0.2810 \\
(0.20)\end{array}$ & & $\begin{array}{c}0.0039 \\
(0.08)\end{array}$ & & $\begin{array}{c}0.8717 \\
(1.43)\end{array}$ \\
\hline Region $\mathrm{x}$ sub-sector $\mathrm{x}$ year dummies & Yes & Yes & Yes & Yes & Yes & Yes & Yes & Yes \\
\hline Farm controls & Yes & Yes & Yes & Yes & Yes & Yes & Yes & Yes \\
\hline Observations & 23,995 & 23,995 & 22,452 & 22,452 & 26,394 & 26,394 & 24,771 & 24,771 \\
\hline Number of establishments & 5,766 & 5,766 & 5,239 & 5,239 & 6,643 & 6,643 & 6,060 & 6,060 \\
\hline R-squared & 0.0814 & 0.0816 & 0.0737 & -0.2269 & 0.1043 & 0.1043 & 0.1070 & 0.0414 \\
\hline
\end{tabular}

0.0814

0.0737

$-0.2269$

0.1043

0.1043

0.1070

0.0414

Results above are for $t=1984,1988,1992,1996,2000$ and 2004. Region $\mathrm{x}$ sub-sector $\mathrm{x}$ year dummies are constructed from three regions and four sub-sectors. The farm controls used are: Age of establishment at time $t$ ( 25 categories), number of employees at time $t$ (11 categories), average tenure at time $t$, and average experience at time $t$. IV estimations are implemented as 2 SLS using the lagged share of immigrants from $t-2$ as instrument(s) (see Section 3 ). 1 st stage $\mathrm{F}$ statistics are as follows: 5.8 (column 3), 7.4, 1.8. and 5.9 (column 4), 17.9 (column 7) and 15.7, 2.3 and 3.3 (column 8). t-values in parentheses. ${ }^{* * *}$, ${ }^{* *}$ and ${ }^{*}$ indicate significance at the 1,5 and $10 \%$ level, respectively. Standard errors are clustered at the establishment level. 
Figure 1: Total employment and wage workers in the agricultural sector, 1980-2008

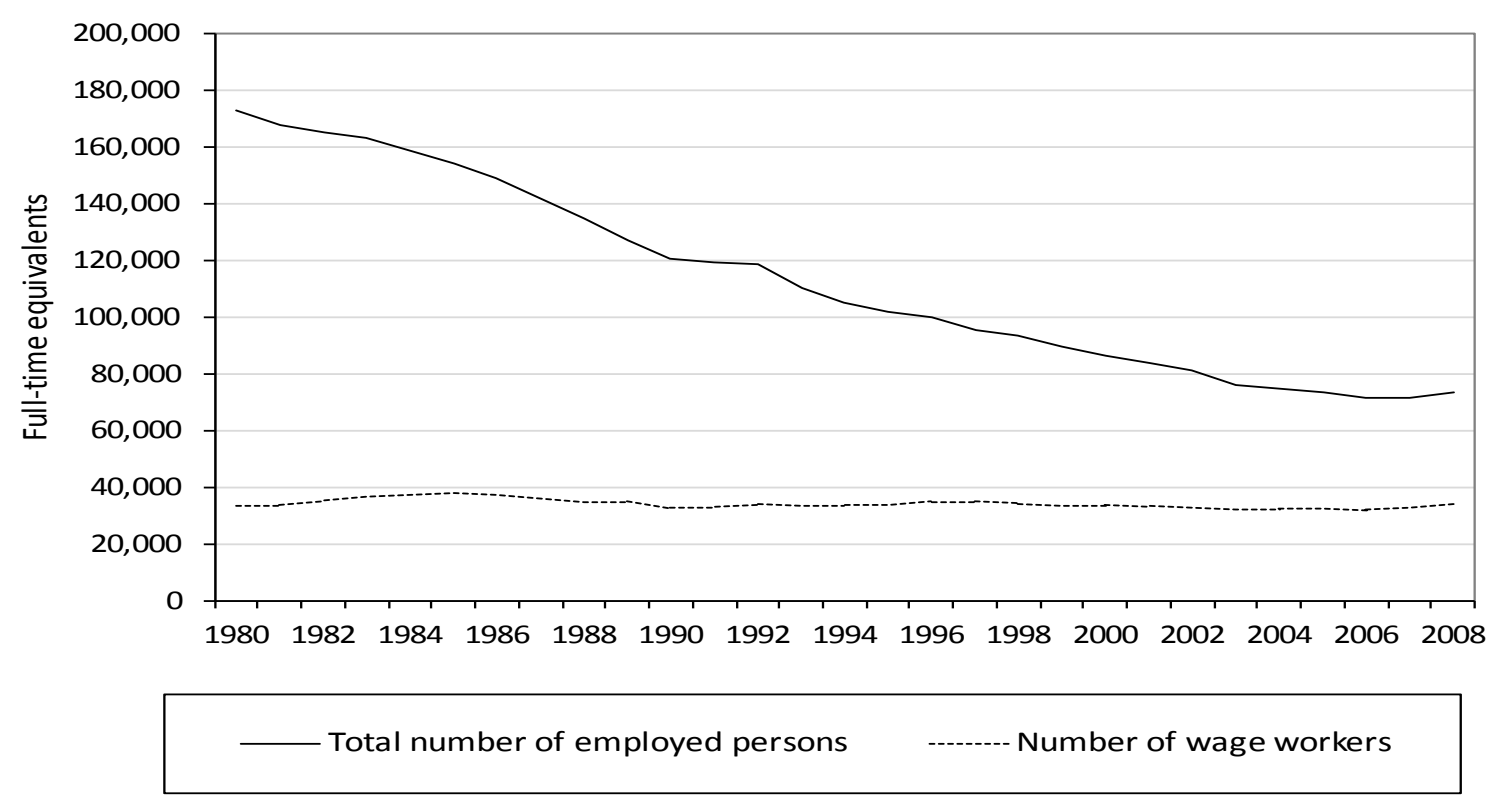

Note: The number of wage workers covers all persons (in full-time equivalents) with a primary occupation as wage worker in the agricultural sector in the last week of November each year. The total number of employed persons also includes employers and self-employed.

Figure 2: Number and average size of agricultural establishments, 1980-2008

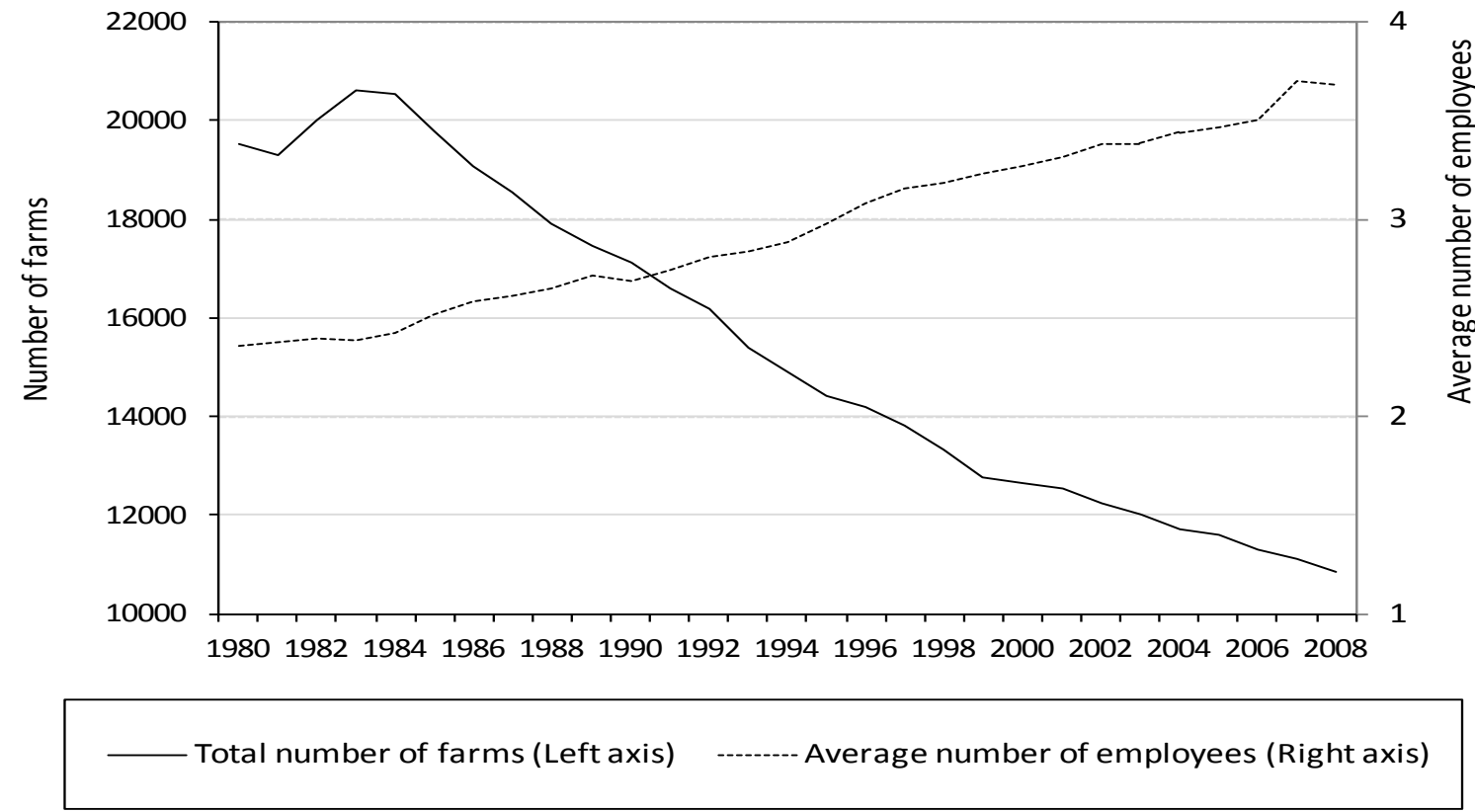




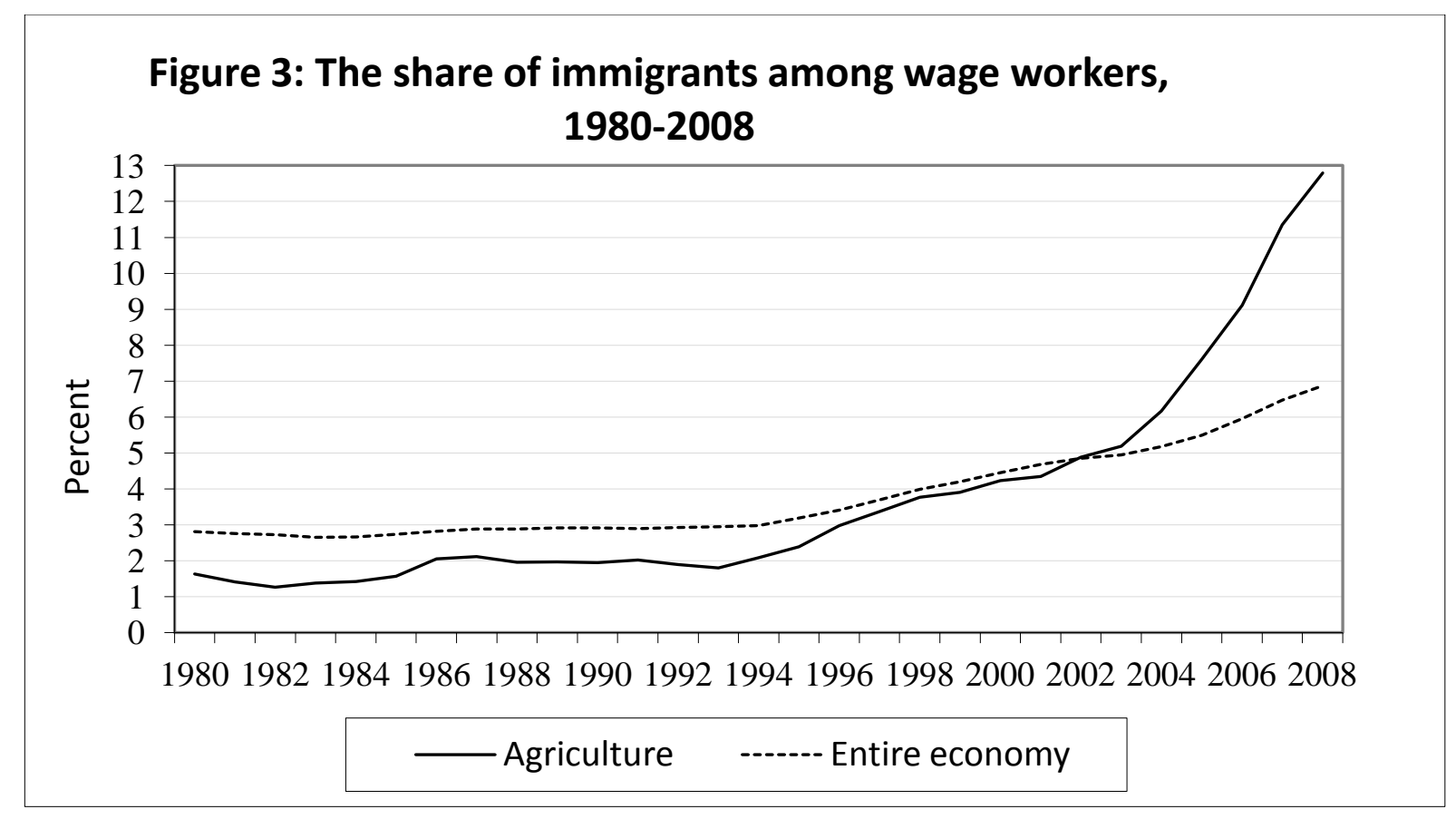

Note: The immigrant shares are calculated from the number of wage workers (in full-time equivalents) in agriculture and the entire economy, respectively, in the last week of November. Wage workers are persons whose primary occupation is wage employment irrespective of their age.

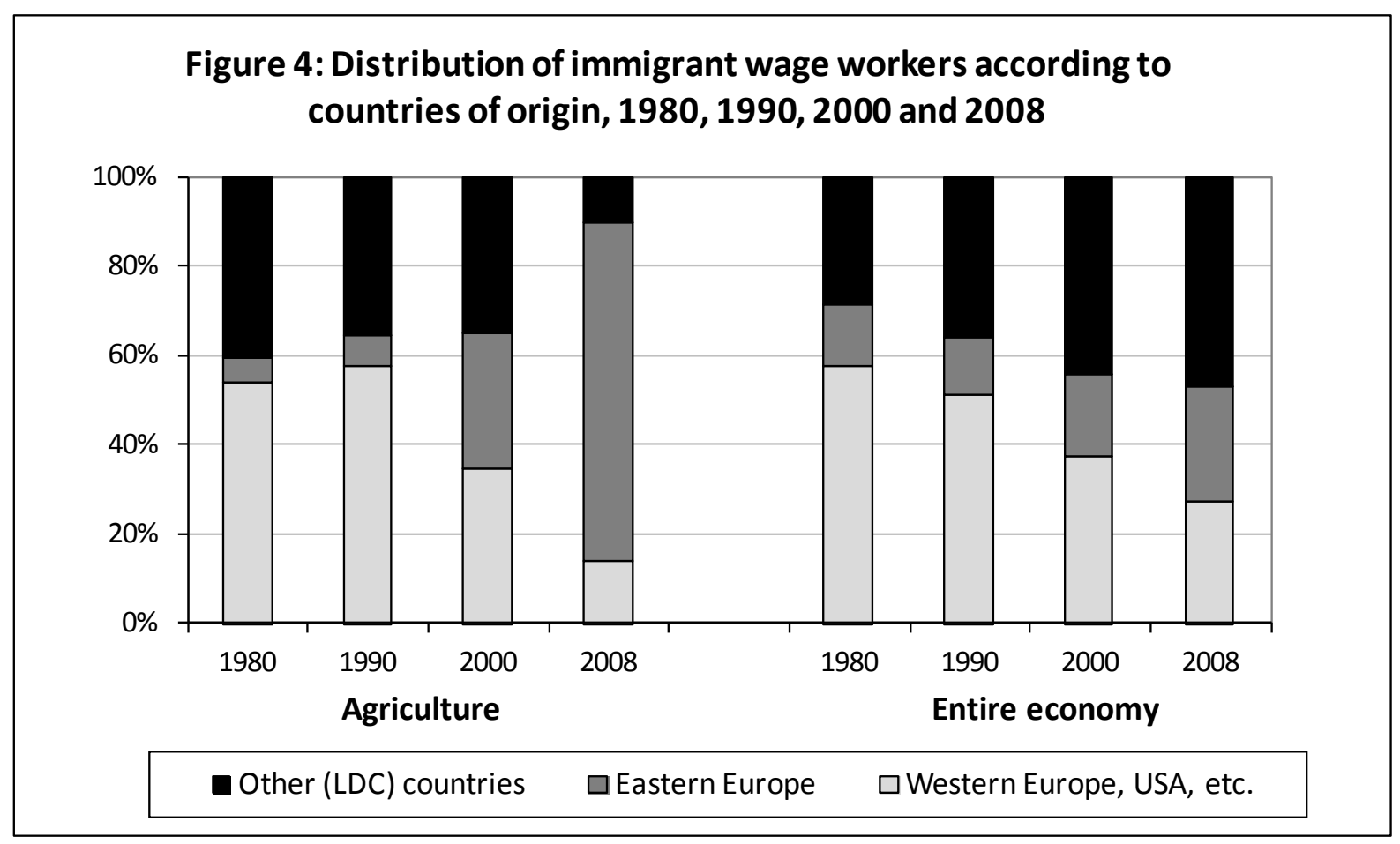

Note: Wage workers are persons whose primary occupation is wage employment irrespective of their age. 